\title{
Switching Tests for the LCTF Protective Dump Circuit
}

W. M. Parsons

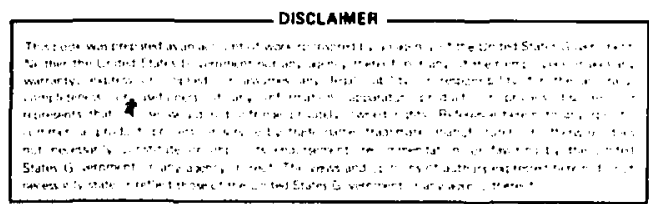

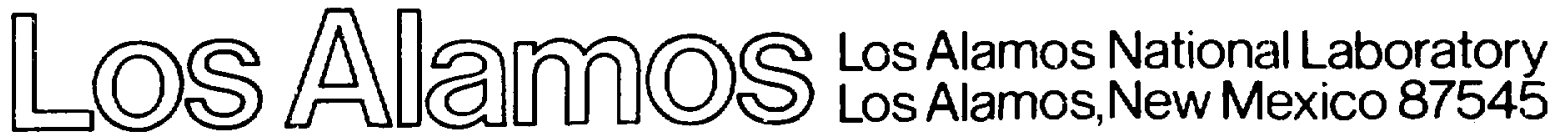




\author{
by \\ N. M. Parsuns
}

ABSTRACT

Each of the six colls in the Large Coll Test Facility (LCTF) has a separate power supply, dump resistor, and swltching circuit. Each swltching clrcuit contalns flve switches, two of which are redundant. The three renalning switches perform separate duties in an emergency dump situation. These three switches were tested to determine their ability to meet the LCTF conditions.

The power supply cruwbar switch in the LCTF is required to close on $25 \mathrm{kA}$ at a low voltage and to carry this current on a continuous basis. An oll cooled, high current bypass switch was successfully tested for over 200 make operatlons at $25 \mathrm{kA}$ and run continuously for seven hours without excessive temperature rise.

The interrupter bypass switch in the LCTF is required to carry $23.2 \mathrm{kA}$ continuously and to interrupt this current and divert it into a parallel connected dc interrupter. It must then withstand a $5 \mathrm{kV}$ arc voltage generated by the dc interrupter followed by a $2.5 \mathrm{kV}$ dump resistor voltage. More than 200 synthetic tests were perfurmed at $25 \mathrm{kA}$ and $10 \mathrm{kV}$. Almust 40 additional tests involving full current transfers and circuit breaker interruptlons were also completed. Both sets of tests were done with and without 011 in the switch. 
The dc interrupter in the LCTF is typically required to divert $25 \mathrm{kA}$ into a $0.1 \Omega, 20 \mu \mathrm{H}$ resistor. This commerclally avallable switch was subjected to over 120 interruptions ranging from 5 to $28 \mathrm{kA}$. Although every interruption was successful, the breaker had considerable truuble interrupting currents with recovery voltages in excess of about $1.5 \mathrm{kV}$. Two interrupters connected in series impruved performance at these higher voltages.

\section{INTRODUCTION}

The Large Col1 Task (LCT) at the Oak Ridge National Laboratory (ORNL) w111 test an array of six superconducting tokamak toroldal fleld colls. The high energy and cost assoclated with each coll necessitates the use of a protective dump circuit in an emergency situation. l Five individual switches and a dump resistor comprise each protective dump circuit. Two of the five switches are redundant.

The three remaining switches are the power supply crowbar switch (PSCS), the Interrupter bypass switch (BP), and the dc clrcult breaker (DCCB). Both PSCS and BP are modifled versions of a switch that was orfginally developed at Los Alamos for use in a high current vacuum interrupter system. ${ }^{2}$ The redundant switches include another interrupter bypass switch and dc circult breaker which are used as a secondary system if the primary system falls.

Figure 1 is a schematic of the protective dump circuit for a single coll.

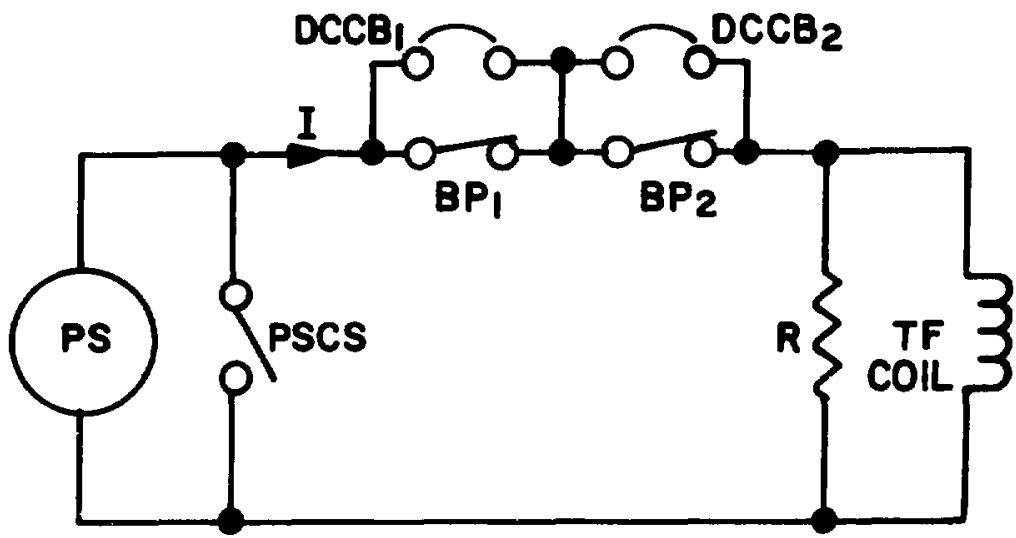

Fig. 1. Protective dump circuit.

The system operates as follows. All switches are Inftially closed except PSCS, and $90 \%$ of the current, $I$, flows through $\mathrm{BP}_{1}$ and $\mathrm{BP}_{2}$, wh1le $10 \%$ flows 
through $\mathrm{DCCB}_{1}$ and $\mathrm{DCCB}_{2}, \cdot$. When a signal is recelved to initiate an emergency dump, a signal is given to PSCS to close and to the power supply to turn off. The closure of PSCS removes the output inductance of the power supply, thus easing the interruption duty of DCCB and also protecting the power supply from any voltage transients. When PSCS has closed, $\mathrm{BP}_{1}$ begins to open. This transfers the full current into $D_{C C B}$. When $B_{1}$ has fully opened, $D_{C C B}$ is given a signal to trip. The opening of $\mathrm{DCCB}_{1}$ creates a high arc voltage and transfers a11 the current to dump resistor, $R$. If for some reason this transfer is not completed, redundant switches $\mathrm{BP}_{2}$ and $\mathrm{DCCB}_{2}$ then open in the same sequence as $\mathrm{BP}_{1}$ and $\mathrm{DCCB}_{1}$.

The six colls in the LCT operate at different maximum currents ranging from 14 to $24 \mathrm{kA}$. The dump resistor will be 0.1 ohms resulting in maximum recovery voltages ranging from 1.4 to $2.5 \mathrm{kV}$. Tests were conducted at currents ranging from 5 to $28 \mathrm{kA}$ and are detalled in the following sections.

\section{THE POWER SUPPLY CROWBAR SWITCH}

The power supply crowbar switch has two baslc duties--to cluse on or make currents as high as $25 \mathrm{kA}$ and to carry this current on a continuous basls. A $25 \mathrm{kA}$ temperature clse test was conducted when the switch was first installed in the test facility. The maximum temperature recorded was on a rocker contact, which ruse $208^{\circ} \mathrm{F}$ over a $78^{\circ} \mathrm{F}$ amblent temperature. The clrculating 011 temperature reached $140^{\circ} \mathrm{F}$. The transient temperature response for varlous points in the PSCS is included in Appendix A.

Figure 2 shows the circult used to test the making abllity of the crowbar switch. A dc current of $33 \mathrm{kA}$ was established thruugh the $20 \mu \Omega$ resistor, $R$, with PSCS open. The switch was then closed. The relative resistance ratio of PSCS and $R$ was such that 25 of the $33 \mathrm{kA}$ flowed thruugh PSCS after closing. The initlal rate of current rise in PSCS was measured to be $1.25 \mathrm{MA} / \mathrm{s}$. Figure 3 is an oscillogram of the current in $R$ during a typlcal make operation. The power supply current, measured by $\mathrm{SH}_{1}$, was essentially constant during the clusure of PSCS. A total of 203 making operations was performed at three-minute intervais. No sign of contact bounce or excessive

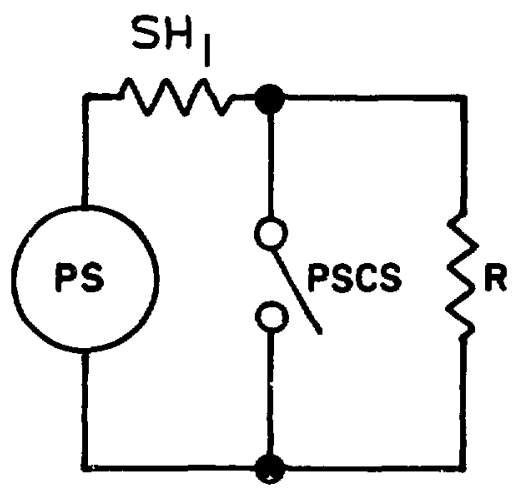

Fig. 2. Test circult for power supply cruwbar sitch. 


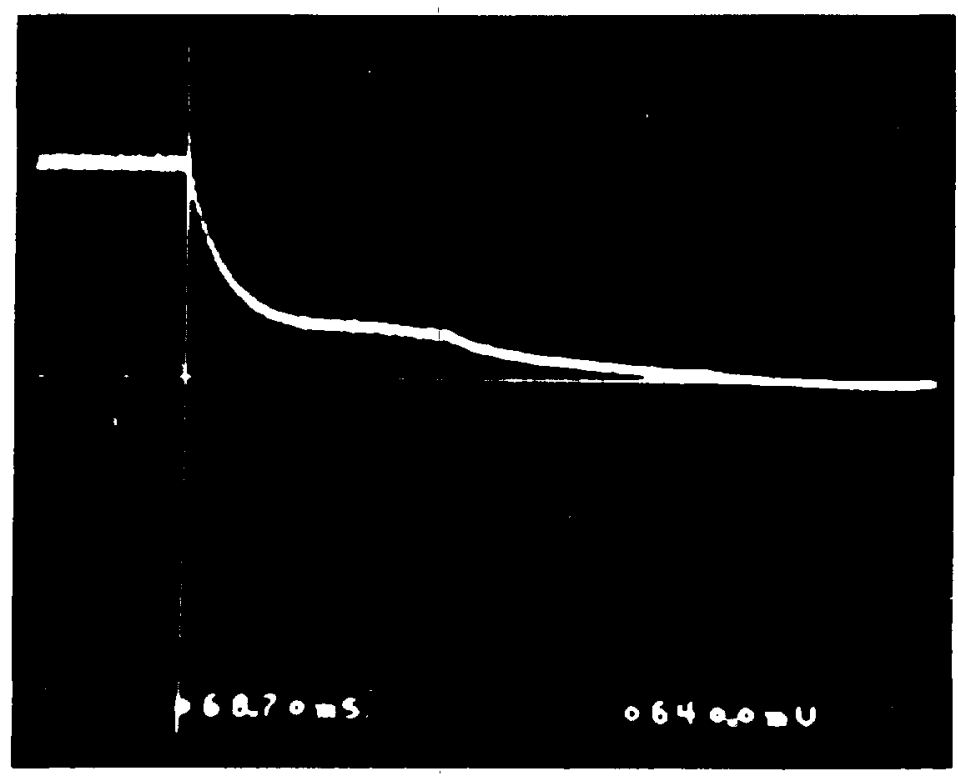

Fig. 3. Current in $R$ during a typical make operation.

erosion was observed. At the conclusion of the make tests another temperature rise test at $25 \mathrm{kA}$ produced a circulating ofl temperature of $130^{\circ} \mathrm{F}$. The detalled translent temperature measurement for this test is also included in Appendix A. This switch should be capable of more than 1000 operations before maintenance should be required. The erosion rate was low and the circulating oll remained clear thruughout the 200 making operations.

\section{THE INTERRUPTER BYPASS SWITCH}

The Interrupter bypass switch also has two baslc dutles, namely, to carry 23. $2 \mathrm{kA}$ continuousiy and to break this current and divert it into the parallel dc circult breaker. The dc clrcult breaker generates arc voltages as high as $5 \mathrm{kV}$ whlle interrupting. After interruption the dump resistor generates a $2.5 \mathrm{kV}$ voltage while absurbing the coll energy. Because the bypass switch is electrically paraliel to buth elements, it must not restrike under the voltages generated.

\section{A. Initial Tests}

The flrst $23.2 \mathrm{kA}$ temperature rlse test, perfurmed when the contacts were new, produced a circulating ofl temperature of $118^{\circ} \mathrm{F}$. The detalled transient temperature response is included in Appendix $A$.

Several transfer uperations were initially performed with the power supply as a current source. These tests shuwed the delay time, transfer time, and arc voltage of the bypass switch. Figure 4 is an oscillogram of the 
voltage acruss this switch during a transfer uperation 111 ustrating these three parameters. The average arc voltage was abut $15 \mathrm{~V}$, while the transfer time was $1.4 \mathrm{~ms}$. The delay time was mensured at $57.4 \mathrm{~ms}$.

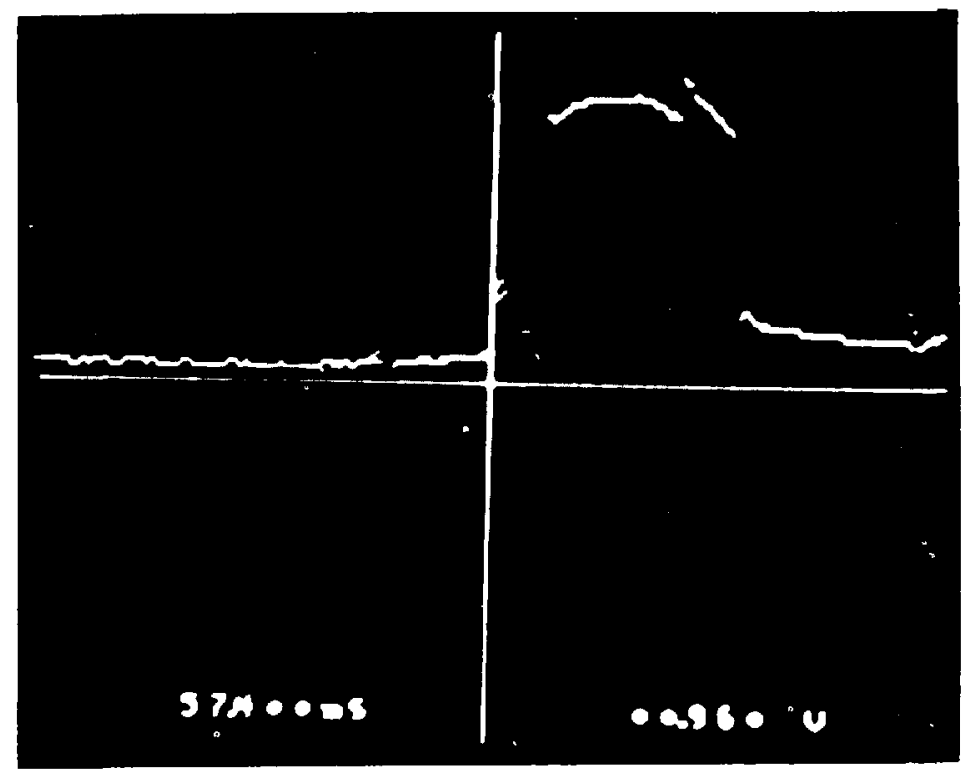

Fig. 4. Voltage acruss BP during transfer uperation.

B. Synthetic Tests

Initially, full power trausfer-intercuption tests began witr both DCCB and $B P$ triggered independent1y. On the third test, nolse triggered DCCB open before BP, and approximately $1 \mathrm{MJ}$ was dissipated in an arc between the open contacts of BP. This prompted a modification, and a special 1imit switch was designed and muunted on BP. This swichch was used to energize the trip coll of DCCB. While parts for this modification were being fabricated, a set of synthetic test:s was performed on BP with the circuit shown in Fig. 5 .

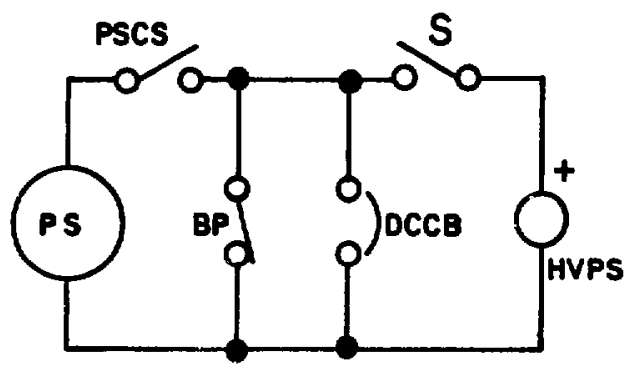

Fig. 5. Synthetic test clrcuit for BP. 
Initially all switches except $S$ were closed, and the power supply PS was set to $25 \mathrm{kA}$. BP was then opened to transfer the full current to DCCB, which then opened. Because of the limited energy stored in the inductance of the power supply loop, the arc In DCCB cleared before moving into the arc chute. PSCS then opened on zero current to provide isolation for the power supply. After a short delay, $S$ was closed to place high voltage across BP. This was intended to simulate the high arc voltage that would have been generated by DCCB, had sufficient energy been stored in the power supply loop. For these tests, the high voltage power supply, HVPS, was set to $10 \mathrm{kV}$. Figure 6 is a diagram detaliing this timing sequence with comparison to the actual voltage stresses that BP w111 see in LCTF. Figure 7 is an oscillogram of the voltage infection waveform as it was actually applied. BP successfully withstood this voltage waveform for 201 consecutive operations.

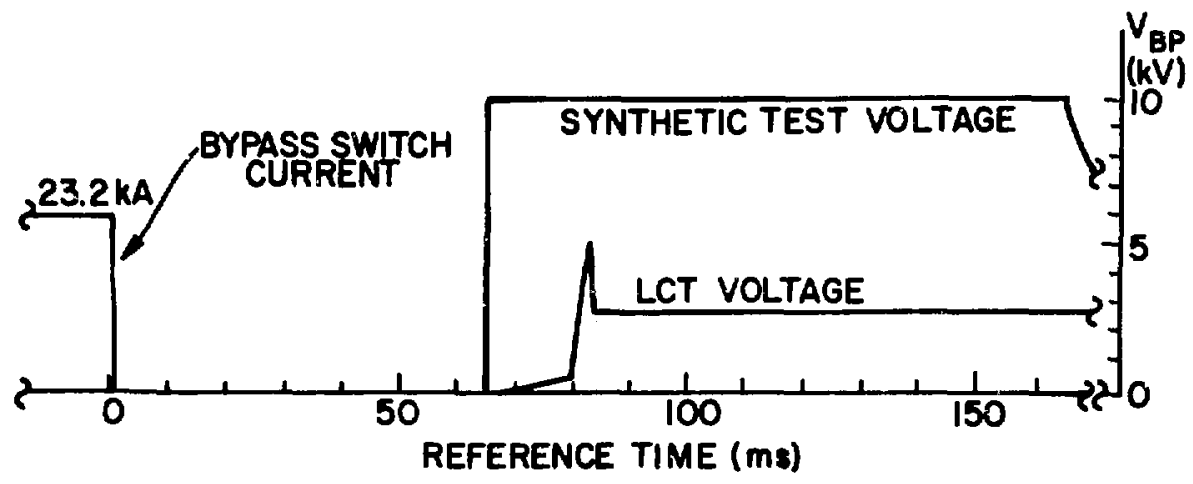

F1g. 6. Comparison of synthetic and anticipated voltage stresses on BP.

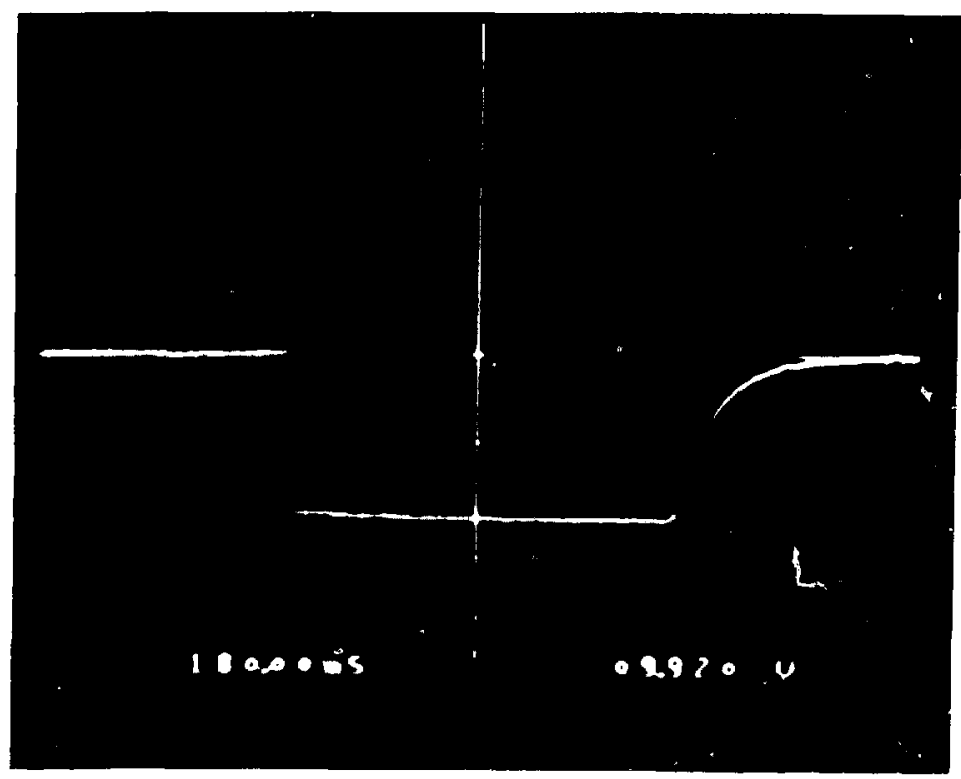

Fig. 7. Voltage injection waveform. 
At the time these tests were taking place, the staff at ORNL was considering elimination of the silicone ofl in BP. Appendix $B$ discusses the problems assoclated with silicone oil. For this reason, the ofl was drained from BP and 14 more operations were performed with the exact timing and voltage as in the previous tests. All were successful in withstanding the $10 \mathrm{kV}$. However, the contact area was blackened from these open air arcs. This blackening from metallic oxldes could lead to tracking problems after many operations.

The air cylinder stroke was then reduced to ha1f of its normal stroke and tests were rerun without ofl. One breakdown appeared in four operations at this reduced stroke. An osc1llogram of this breakdown in shown in Fig. 8.

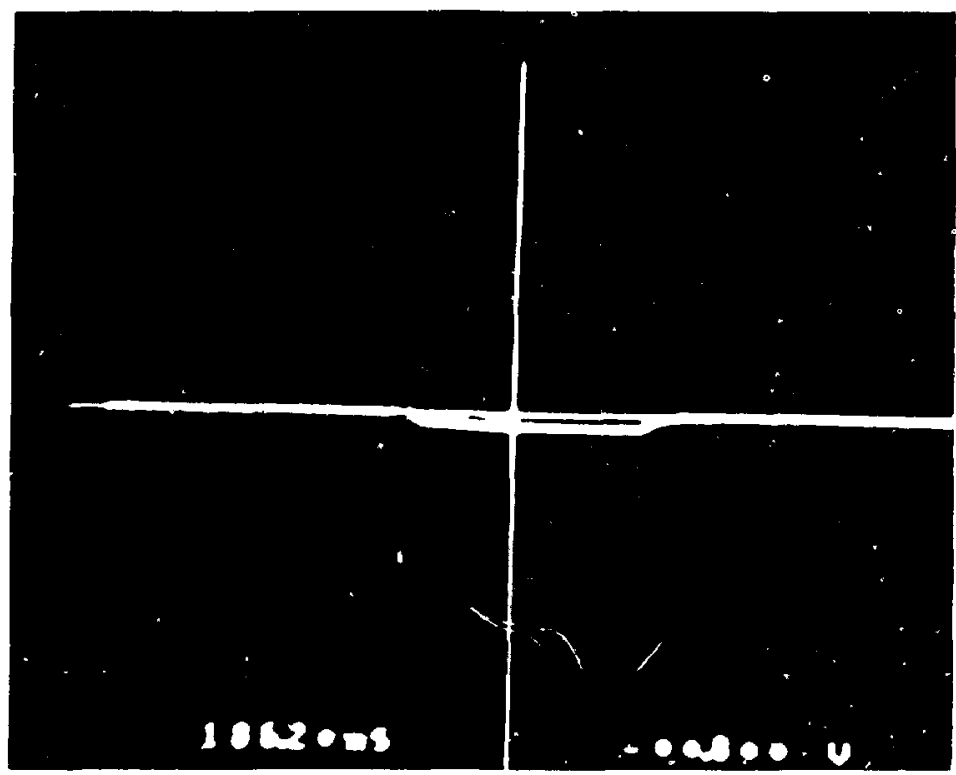

Fig. 8. Voltage breakdown at $10 \mathrm{kV}$ with reduced stroke.

In conclusion it is feit that BP can operate safely in either afr or siltcone oll. If run in oll, the film deposition aind gas generation problems in Appendix $B$ should be noted. If run in a1r, increasd maintenance is recommended to remove the metallic oxides from the contacts and finsulating surfaces resulting from open alr arcing.

C. Fu11 Power Tests

After the new 1 imit switch mechanism was installed on BP, full power transfer and interruption tests proceeded. An Inductor was charged to currents as high as $28 \mathrm{kA}$ by a capacitor bank. This Inductive current was distributed between BP and DCCB as described in the introduction. BP was then opened and transferred all the curcent to DCCB. DCCB then Interrupted and diverted the inductive current into the dump resistor. Due to the current decay assoclated with the nonsuperconducting coll used in these tests, DCCB was upened before BP reached full struke. This condition 1.3 mure severe than 
LCTF conditions, which will allow BP to be fully open before DCCB is tripped. For these tests, DCCB was tripped $15 \mathrm{~ms}$ after BP began to open. Because DCCB has a $20 \mathrm{~ms}$ delay and requires $10 \mathrm{~ms}$ to generate $\mathrm{h}$ hg arc voltages, the contacts on BP were $90 \%$ upen when DCCB began to generate high arc vultage.

Tests were again performed with and withuut ofi in BP. During the 20 tests with 011 and 18 tests without ul1, BP perfurmed its transfer uperaton and whthstood the resulting recovery vultages successfully. Typlcal DCCB ar: voltages ranged from 3.5 to $5 \mathrm{kV}$. Occaslonally, inductive splkes at Interruption caused voltage translents as high as $8.3 \mathrm{kV}$ to appear acruss BP. The switch contacts examined after these test showed some erusion and pitting, although not severe.

This switch, if run in oil, should be able to perform at least 1000 operations before maintenance of the contacts is required.

\section{Fallure to Transfer Test}

A test was performed on BP to determine the maximum arc voltage generated by fully open contacts at high currents. This situation would uccur if the parallel DCCB were opened before BP and current transfer became 1mpossible. For this test, DCCB was held open, and the capacitor bank was discharged through BP as in the full power tests in section III.C. Contacts parted un $21 \mathrm{kA}$ approximately $8 \mathrm{~ms}$ after current inftlation. Figures $9 \mathrm{a}$ and $9 \mathrm{~b}$ are the respective current and voltage waveforms for BP during this test. The peak arc voltage measured was $144 \mathrm{~V}$, whlle the average voltage was about $130 \mathrm{~V}$. 


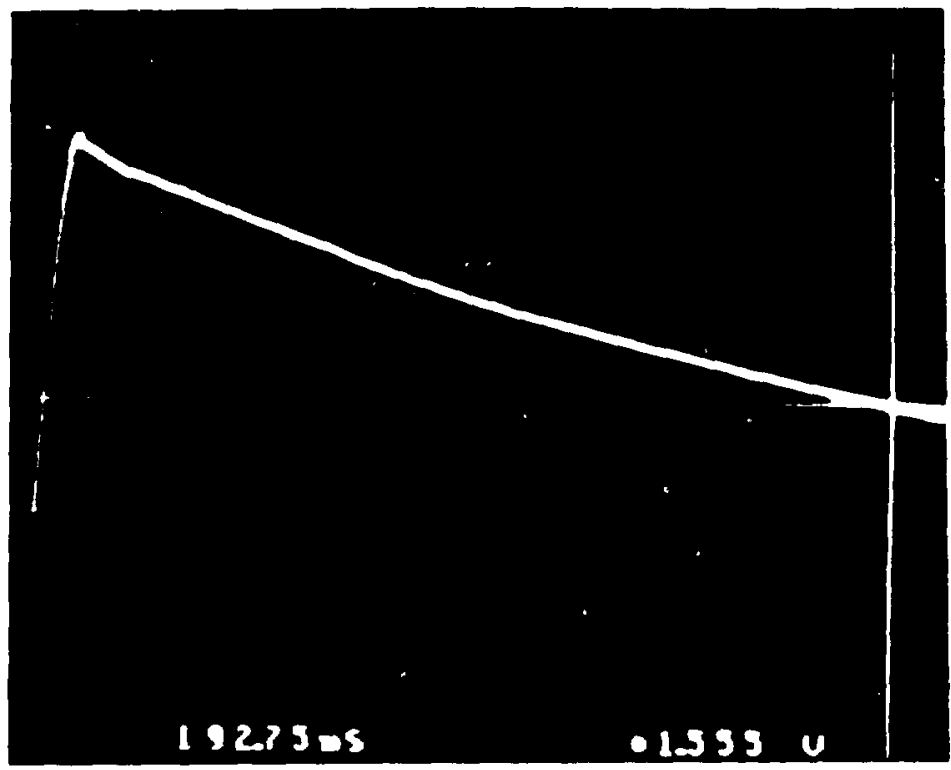

(a)

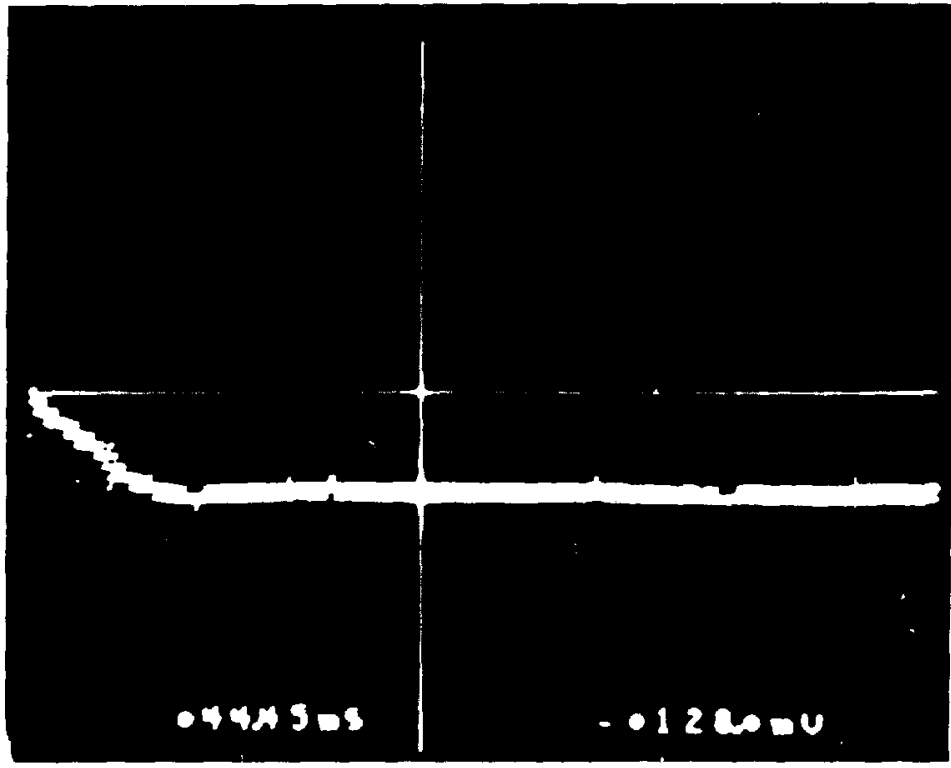

(b)

Fig. 9. Waveforms for BP arcing test.

a. Current.

b. Voltage. 
IV. THE dC INTERRUPTER

The dc interrupter selected by ORNL for use in the LCTF was a Westinghouse type DMD, seral-high speed, alr magnetic clrcult breaker. This interrupter has a $4 \mathrm{kA}$ continuous current rating, a $1.5 \mathrm{kV}$ nominal voltage rating, and was equipped with a special $5 \mathrm{kV}$ arc chute for this application.

Tests began with the circuit of Fig. 10. In this circuit DCCB and BP are initalily closed, $S$ is open, and $C$ is precharged. S now closes and $C$ discharges through $L$. $D_{1}$ crowbars $C$ when $L$ has reached peak current and traps the inductive current in the circuit breaker leg. Now, BP opens to transfer the full current into DCCB, which then opens. The arc voltage of DCCB forces the current into $R$, which completes the protective dump operation. The value of $C$ was $9.5 \mathrm{mF}$, L was elther 3.7 or $4.5 \mathrm{mH}$, and $R$ was varled between 60 and $170 \mathrm{~m} \Omega$ to obtain different recovery voltages for a given current.

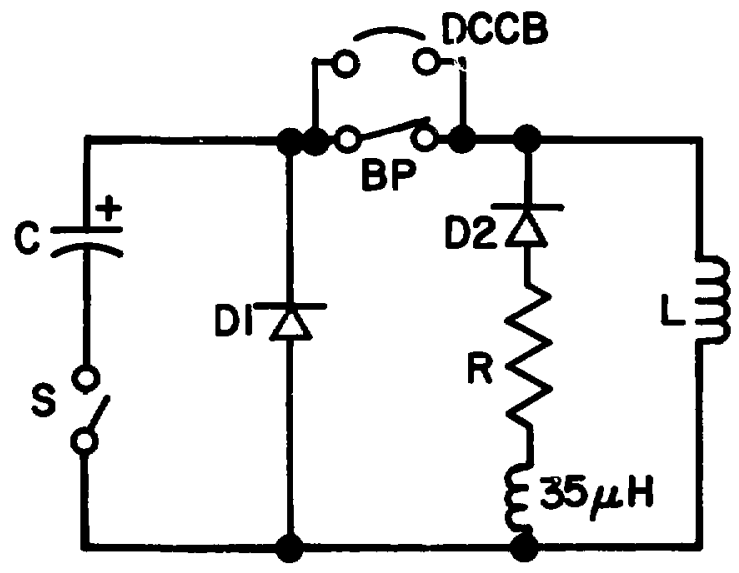

Fig. 10. Circuit breaker test schematic.

A. Tests on a Single dc Interrupter

Figure 11 shows current and voltage waveforms from a $7 \mathrm{kA}, 1.5 \mathrm{kV}$ interruption. BP opened at $7.5 \mathrm{~ms}$ to transfer current into DCCB, which interrupted at $42 \mathrm{~ms}$. The peak arc voltage generated by DCCB was $1.9 \mathrm{kV}$, while the steady state recovery voltage was $1.5 \mathrm{kV}$.

Most of the tests run on a single interrupter did not involve a prior current transfer from BP. This allowed higher interruption currents to be achieved because BP did not need to reach full stroke.

Almost 100 interruptions were performed on a single dc interrupter with currents between 5 and $28 \mathrm{kA}$ and recovery voltages ranging from 0.8 to $2.6 \mathrm{kV}$. All interruptions were successful. When the recovery voltage was under about $1.5 \mathrm{kV}$, interruptions were generally quite clean and very quick as shown in the current waveform of $\mathrm{Fig}$. 11. Wher. $R$ was changed to higher values and produced recovery voltages greater than $1.5 \mathrm{kV}$, interruptlons were not as clean or quick. Figure 12 shows the current and arc voltage waveforms for a $19.5 \mathrm{kA}, 2460 \mathrm{~V}$ interruption. Each dip in the current waveform corresponds to 


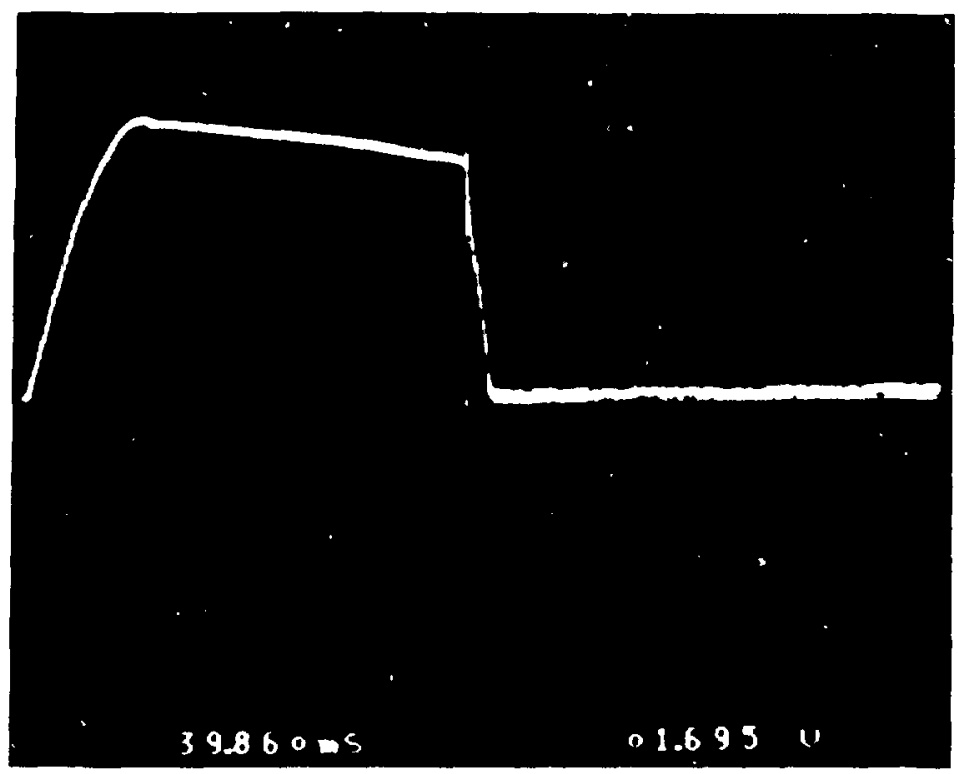

Fig. 11a. Breaker current from a $7 \mathrm{kA}, 1.5 \mathrm{kV}$ interruption with full transfer by BP.

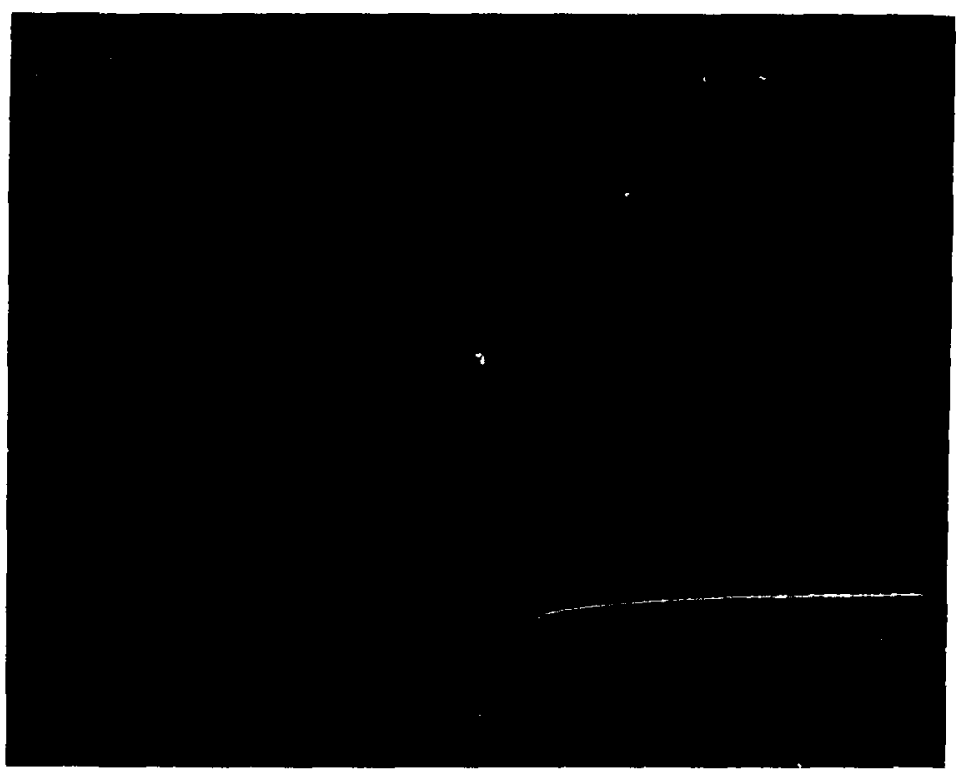

FIg. 11b. Breaker voltage from a $7 \mathrm{kA}, 1.5 \mathrm{kV}$ interruption with full transfer by $B P$. Peak arc voltage is $1.9 \mathrm{kV}$. 


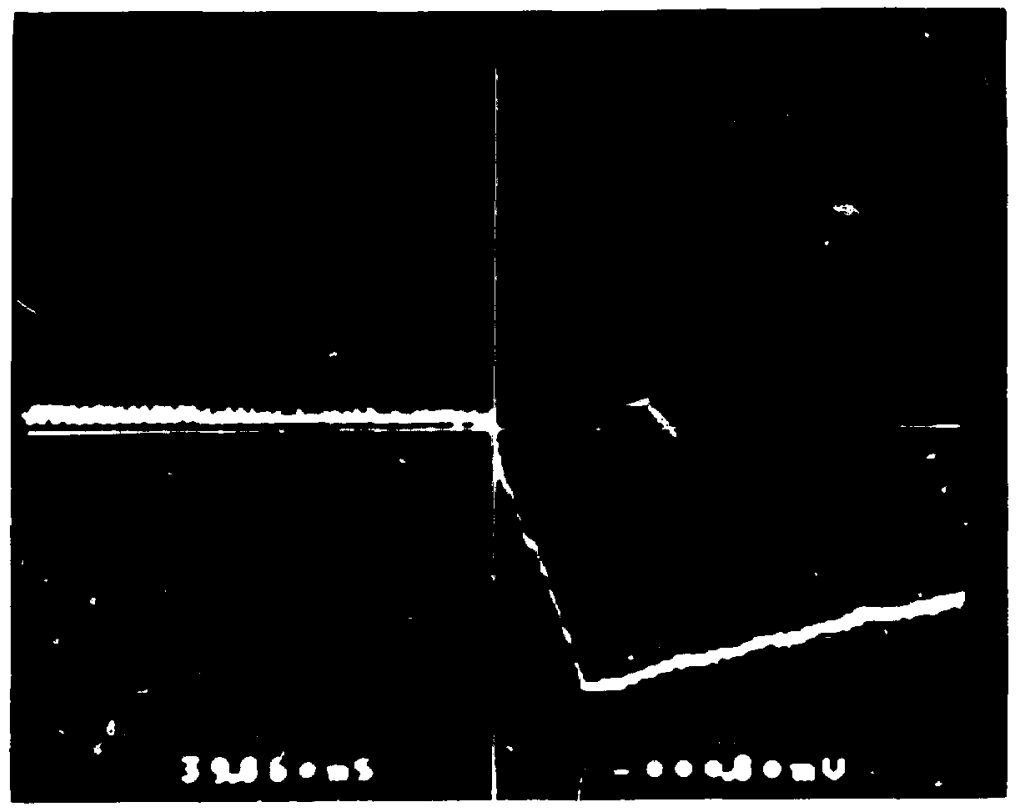

Fig. 11c. Resistor current from a $7 \mathrm{kA}, 1.5 \mathrm{kV}$ inteription with full transfer by BP. Transfer current is $5.5 \mathrm{kA}$.

a peak in the arc voltage waveform. The circuit breaker was prubably restriking on the lower contacts while the primary arc was in the arc chute. This restrike effectively shorted the high voltage arc with a low vultage arc. The current then transferred from the parallel resistor back to the ctrcuit breaker. The arc on the lower contacts then moved up into the arc chute and the process repeated. Eventually the breaker cleared, possibly due in part to the uprush of heated gas generated by the prolonged aring prucess.

To verify that the restriking process was dependent on recovery vultage, a number of tests were conducted where $R$ was reduced to lower the recovery voltage. Although the restriking process continued, the magnitude and frequency of restrikes was diminished. Compare the current waveform of Fig. 13, which had a $1.4 \mathrm{kV}$ recovery voltage, to the current waveform of Fig. 12 with a $2.46 \mathrm{kV}$ recovery voltage. Both Interruptions were at the same current. This interruption was typical of the kind of impruvement seen when the recovery voltage was lowered. To gather sume statistical evidence related to recovery voltage influence, each test was analyzed for the number uf loups or restrikes occurring during that interruption. These data are presented in Table $I$. In the entry $X / Y, X$ is the number of tests performed at a given current and voltage level, and $Y$ is the average number of loops or restrikes during the tests. 


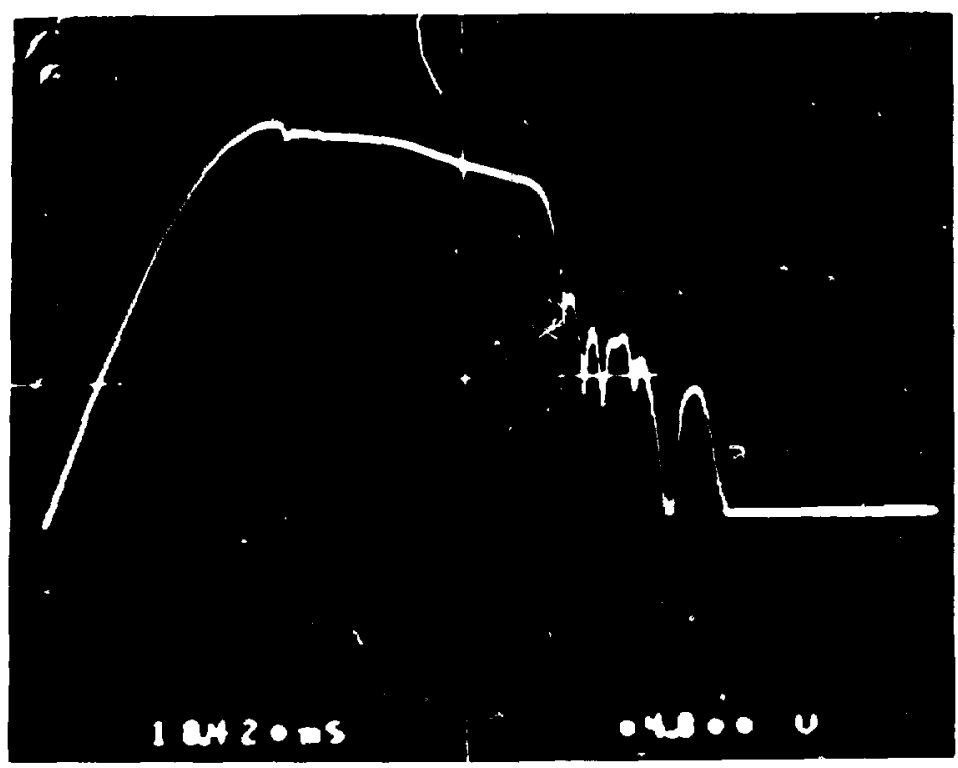

(a)

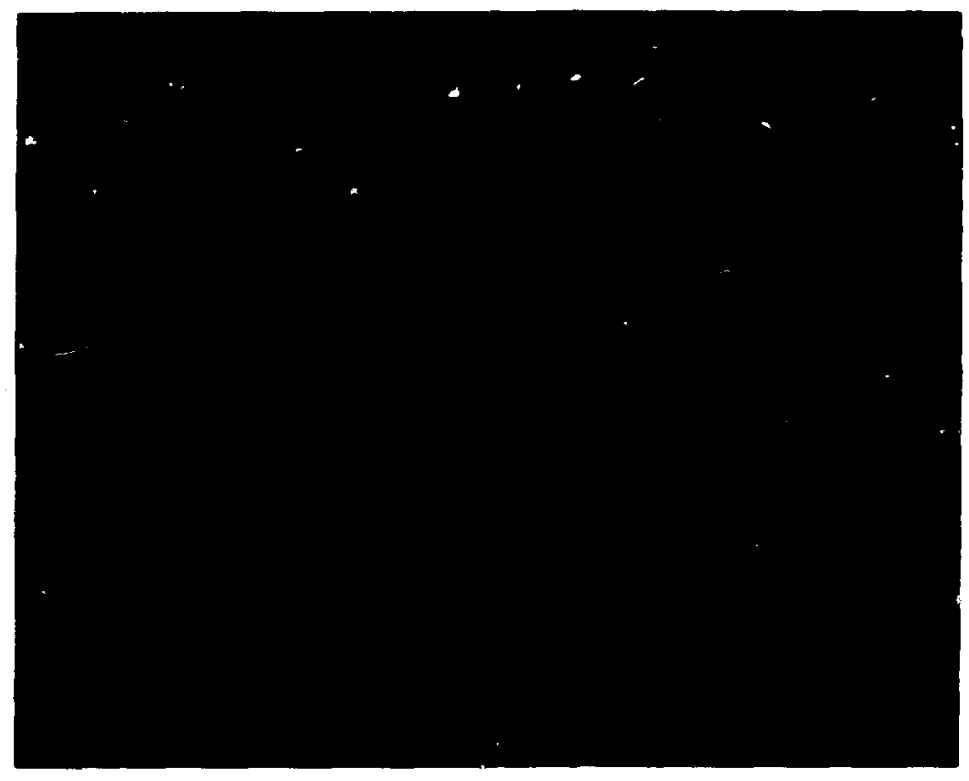

(b)

Fig. 12. Waveforms from a $19.5 \mathrm{kA}, 2.46 \mathrm{kV}$ interruption. (Time scales are different.)

a. Breaker current.

b. Breaker voltage. 


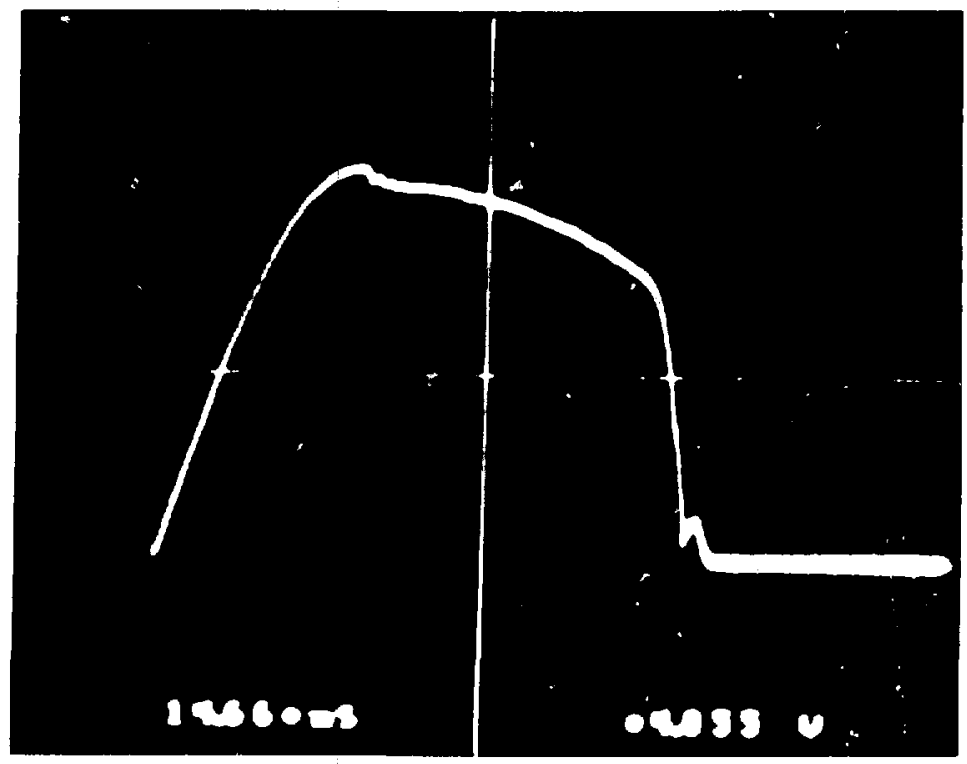

Fig. 13. Current waveform for a $19.5 \mathrm{kA}, 1.4 \mathrm{kV}$ recovery voltage.

\section{TABLE I}

RESTRIKE DATA FOR SINGLE INTERRUPTER TESTS

$X / Y$ IS ENTRY WHERE $X=$ NUMBER OF TESTS

AND $Y=$ AVERAGE NUMBER OF RESTRIKES

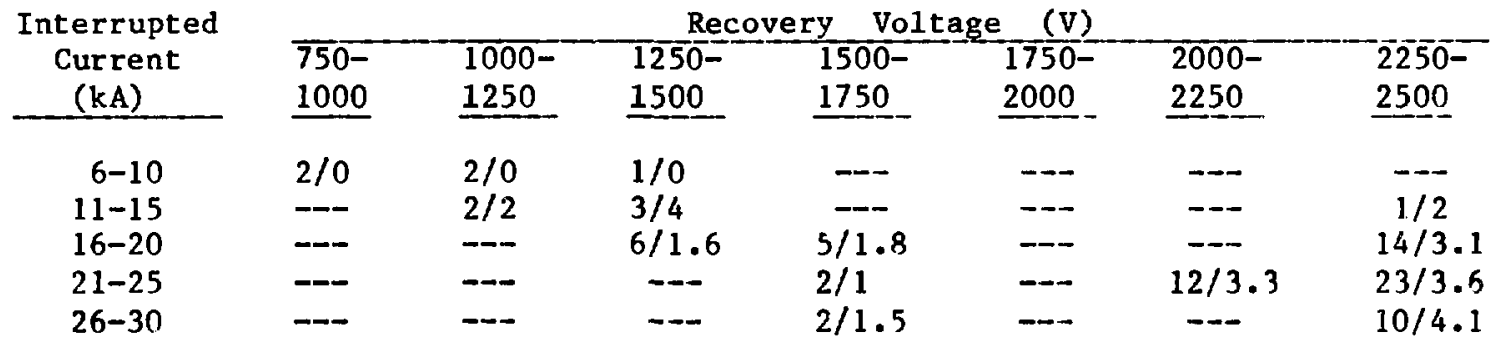

As can be seen in the table, the average number of restrtkes increases significantly from left to right but only slightly from top to bottom. These trends indicate that the restriking is more dependent on high voltages than on high currents. Regardless of recovery voltage, restriking was somewhat more frequent with the high current interruptions. 
B. Tests on Two dc Interrupters In Series

In an attempt to obtain high voltage, restrtke free interruptions, the ORNL staft requested that two series connected dc circult breakers be tested. Two sets of full current transfers and interruptions were performed at currents ranging from 3 to $20 \mathrm{kA}$. Peak currents were reduced slight ly frum previous tests due to the current decay while BP reached full contact separation. The two sets of tests differed in that ofl was removed from $B P$ for the second set. Because this did not affect the performance of the dc interrupters, the two test results are considered together for the remainder of this report.

A11 the 38 interruptions in this set of tests were successful. However, the attempt to obtain restrike free interruptions at high recovery voltages was only partially successful due to the high jitter of the circult breakers. When both interrupters opened simultaneously, interruption was quite good. Figure 14 shows the current and voltage waveforms for a $19.6 \mathrm{kA}, 2.24 \mathrm{kV}$ interruption where both interrupters opened simultaneously. The two traces on the voltage waveform are the midpoint and full voliage traces. Notlce the even voltage sharing during and after the arcing process.

Simultaneous upening was achleved only about $25 \%$ of the time. The rest of the time, one of the breakers would open earlier than the other, and the restriking prucess would occur until the switch cleared or unt 1 the other breaker opened sufficlently to assist. Flgure 15 is representative of such an interruption. Notice on the voltage waveform that the midpoint and full voltage traces cross. This is caused by one breaker not generating any arc voltage during interruption and not sharing any recovery voltage until the other breaker has already interrupted. Also notice that the restrike loops are fewer and smaller than those seen during tests on a single interrupter. Despite the mostly nonsynchronous openings, the bulk of these tests showed that the series connected interrupters had a positive effect in reducing the size and number of restrikes.

C. Comment on Application of a dc C1rcult Breaker for Col1 Protection

The requirements placed on an interrupter for coll prutection are unlike the requirements for dc interrupters in standard applications. These interrupters are typlcally used to clear faults in traction motor service and are not used with a parallel resistor. In traction service, once the current has been reduced to a low level by the breaker's arc voltage, it cannot quickly rise again. If the breaker were to restrike, the new arc would be forced into the arc chute before the fault current had a chance to rise to significant levels. Indeed, NEMA standards specify the maximum $\mathrm{d} 1 / \mathrm{dt}$ for simi-high speed dc breakers to be $5.0 \mathrm{~A} / \mu \mathrm{s}$. The time measured for a typlcai resi-lke to reach full arc voltage was about 600 us. In a traction system this wivld amount to a maximum restrike current of $3.0 \mathrm{kA}$. In the LCT applicalion, however, the current in the system is essentially constant. When the breaker restrikes, the cotl current can rapidly move from the parallel resistor back into the clrcult breaker. This restrike $\mathrm{di} / \mathrm{dt}$ was found to be as high as $25 \mathrm{~A} /$ IIs. Because of this, restrikes frequently ieached levels of 


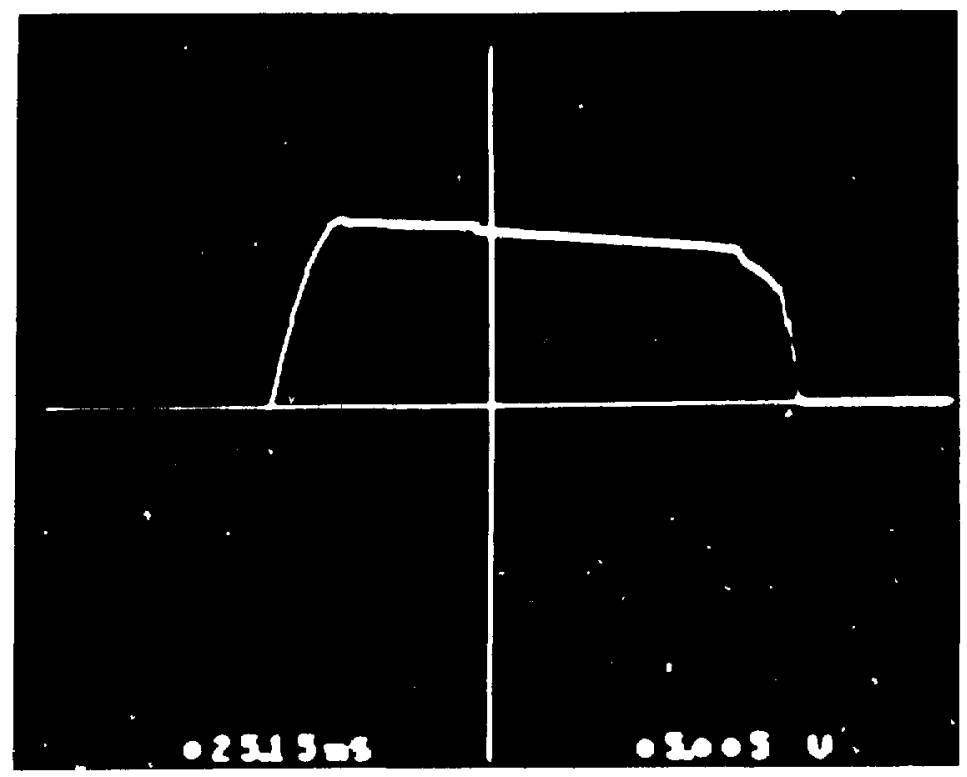

(a)

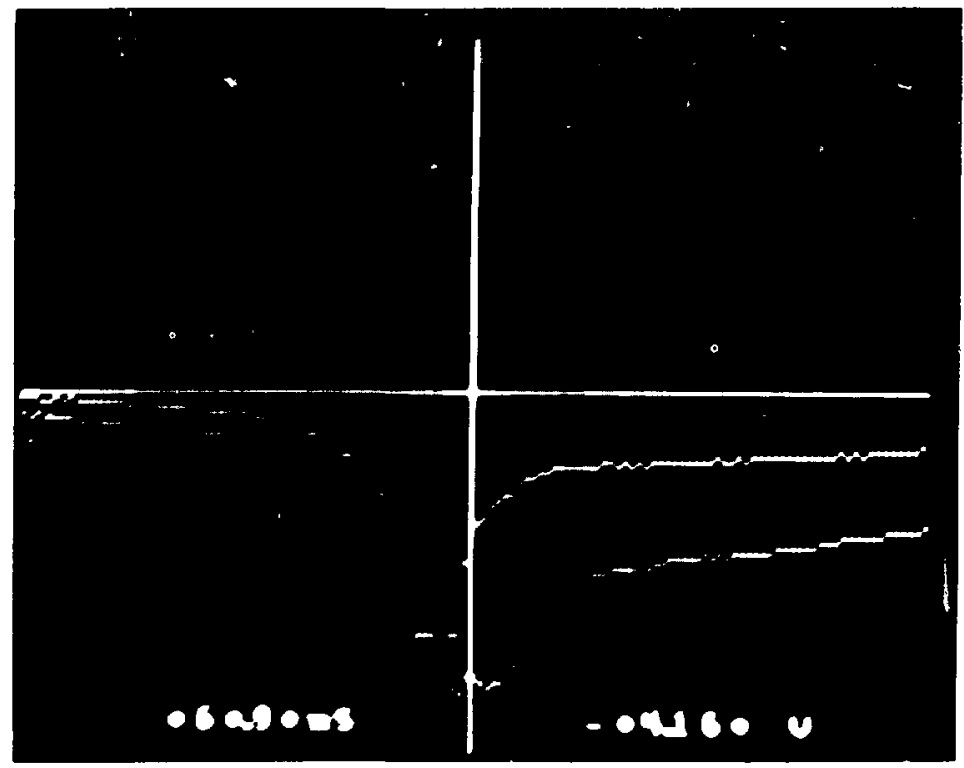

(b)

F18. 14. Waveforms for a $19.6 \mathrm{kA}, 2.24 \mathrm{kV}$ interruption with both interrupters upen simultaneously. a. Breaker current.

b. Breaker midpoint and full voltage. 


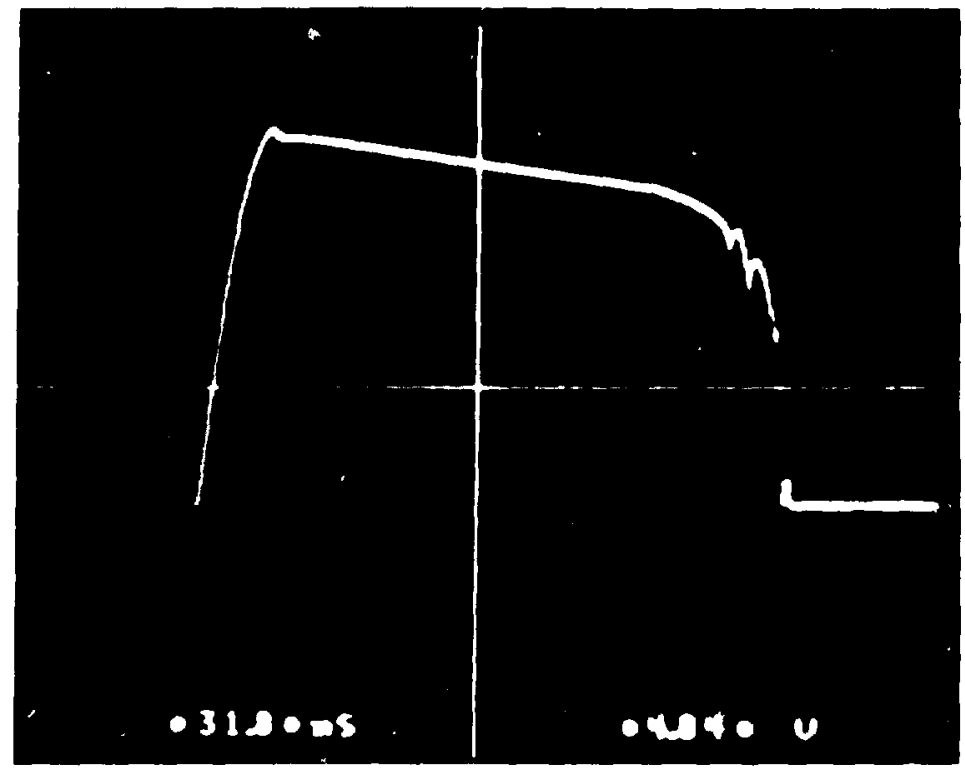

(a)

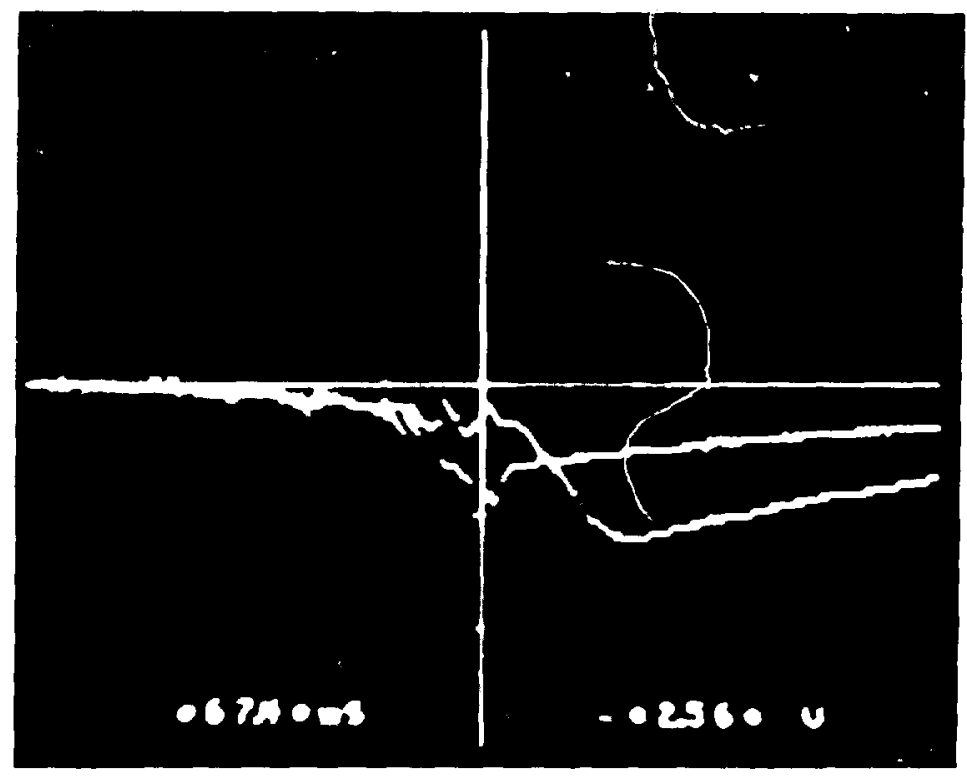

(b)

F1g. 15. Waveforms for a $19.4 \mathrm{kA}, 2.4 \mathrm{kV}$ interruption with both interrupters not opening simultaneously. a. Breaker current.

b. Breaker midpoint and full voltage. 
15 to $20 \mathrm{kA}$. The restriking process is not uncommon in traction applications, but because the magnitude is limited, the problem is not as severe.

If a significant Inductance were added in serles with the dump resistor, the restrike $\mathrm{di} / \mathrm{dt}$ could be reduced. Calculations indicate that this inductor would have to be on the order of $0.5 \mathrm{mH}$ to reduce the $\mathrm{dl} / \mathrm{dt}$ to $5 \mathrm{~A} / \mathrm{us}$. Thls would be counter productive as initial current transfer to the resistor would be more difficult to accomplish. Also, $156 \mathrm{~kJ}$ of energy dissipation in the arc chute would be added at $25 \mathrm{kA}$. Because the breaker $1 \mathrm{~s}$ only rated at $160 \mathrm{~kJ}$, the device would be over stressed for energy absorption. In addition, restrikes probably would not be eliminated but simply reduced in magnitude. There may exist an intermediate optimum that results in minimum erusion for the interrupter; however, this minimum would be difficult to determine theoretically. The basic problem seems to arise from using the device at voltages greater than its normal rating.

\section{CONCLUSIONS}

The power supply crowbar switch and the interrupter bypass switch were both able to carry their continuous design currents of 25 and $23.2 \mathrm{kA}$ and successfully perform thelr respectlve making and breaking dutles. No adverse erosion was detected in either device after several hundred operations. These devices should be able to operate more than 1000 times before maintenance is required. In addition, the bypass switch was found to operate rellably with or without ofl at twice the expected recovery voltage.

The dc clrcult breaker had no fallures to interrupt in any of the tests performed. Interruption currents ranged from 5 to $28 \mathrm{kA}$, while recovery voltages varled from 0.8 to $2.6 \mathrm{kV}$. Interruptions with recovery voltages greater than the $1.5 \mathrm{kV}$ rating of the device were characterized by multiple restrikes before final current clearing.

Tests with two clrcult breakers in serles showed some Improved current clearing time, although this improvement was strongly dependent on the simultaneous oprning of both breakers. The simultaneous opening was achleved on1y about 25\% of the time because of the jitter of the devices. A trend toward reduced restrike magnitude was exhibited even when the breakers did not open simultaneously.

\section{REFERENCES}

1. W. M. Parsons, R. J. Wood, "Protective Clrcults for Superconducting Magnets," Proc. 4th ANS Toplcal Mtg. Tech. Controlled Nuc. Fus., King of Prussia, PA, Oct. 14-17, 1980.

2. E. M. Honig, R. W. Warren, "The IJse of Vacuum Interrupters and Bypass Switches to Carry Currents for Long Tlmes," Proc. 13th Pulse Power Modulator Sym., Buffalo, NY, June 20-22, 1978. 
Figure $A 1$ is the inttial temperature rise test data for BP and PSCS at 23.2 and $25 \mathrm{kA}$, respectively. This test was performed before any make or break tests were done. F1gure A2 is the temperature rise test for the same switches after approximately 200 make or break tests on each switch. The following references apply to the traces on Figs. Al and A2 and Include the maxinum temperatures recorded.

\section{Reference Al}

\begin{tabular}{crr} 
Trace & Description & Max. Temp \\
\cline { 2 - 2 } 1 & ambient a1r & 78 \\
2 & BP o11 & 118 \\
3 & PSCS o11 & 140 \\
4 & BP main terminal & 190 \\
5 & BP main termina1 & 196 \\
6 & PSCS main terminal & 234 \\
7 & BP rucker guide & 234 \\
8 & PSCS ma1n terminal & 246 \\
9 & BP rucker guide & 254 \\
10 & PSCS rucker termina1 & 262 \\
11 & PSCS rocker guide & 264 \\
12 & PSCS rucker termina1 & 286
\end{tabular}

\section{Reference A2}

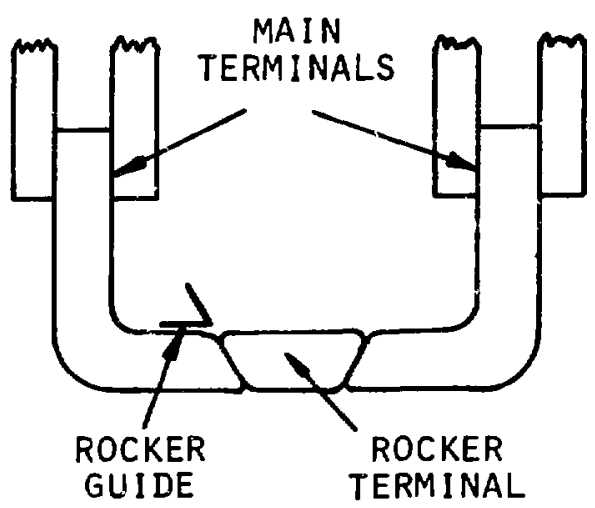

\begin{tabular}{clc} 
Trace & \multicolumn{1}{c}{ Description } & Max. Temp ${ }^{\circ}$ F \\
\cline { 1 - 2 } 1 & ambient alr & 122 \\
2 & BP ofl & 128 \\
3 & PSCS ol1 & 198 \\
4 & BP rucker terminal & 210 \\
5 & PSCS maln terminal & 238 \\
6 & BP maln terminal & 240 \\
7 & BP rucker guide & 250 \\
8 & PSCS rucker terminal & 266 \\
9 & PSCS rucker gulde &
\end{tabular}

KEY 


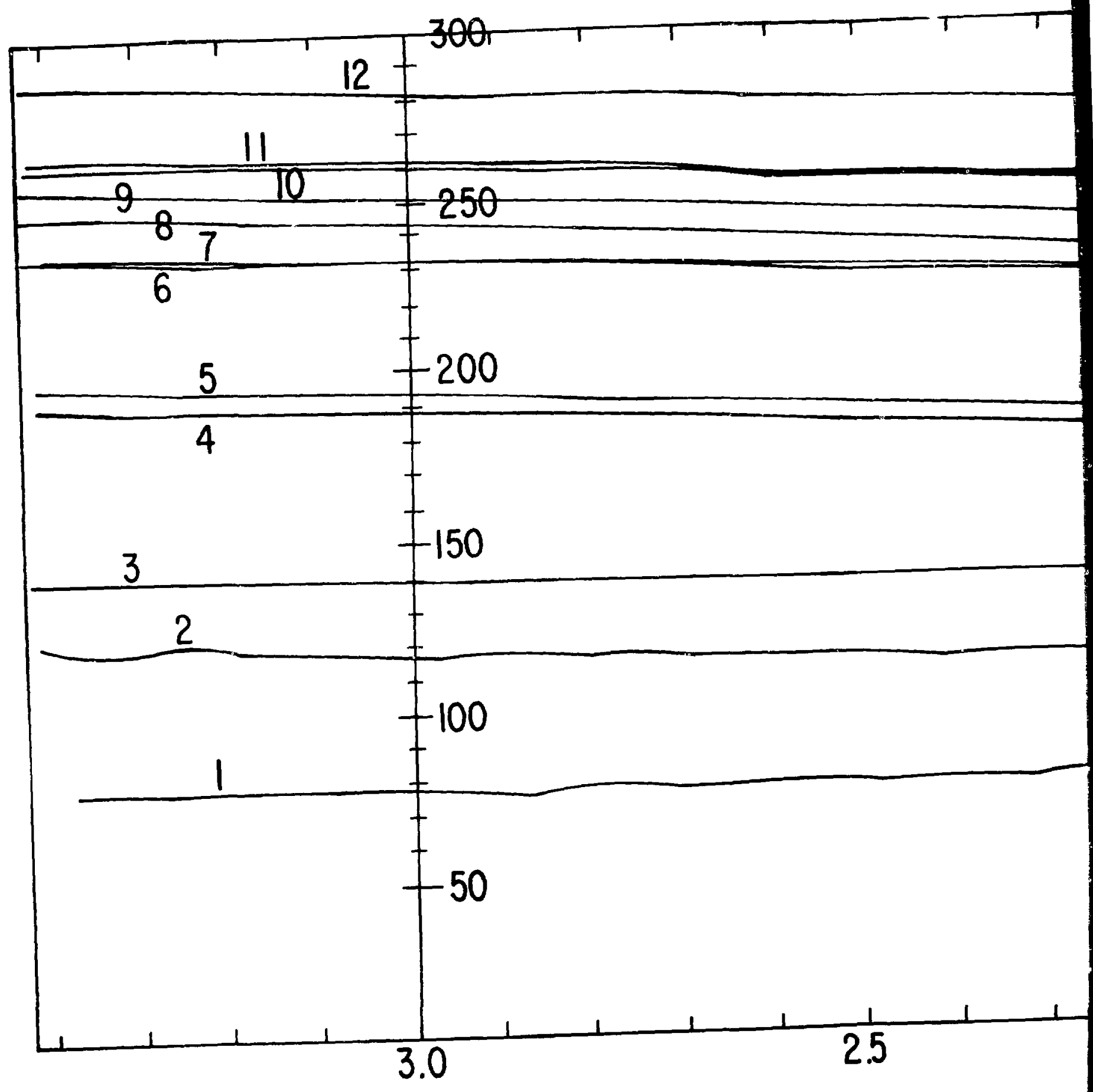




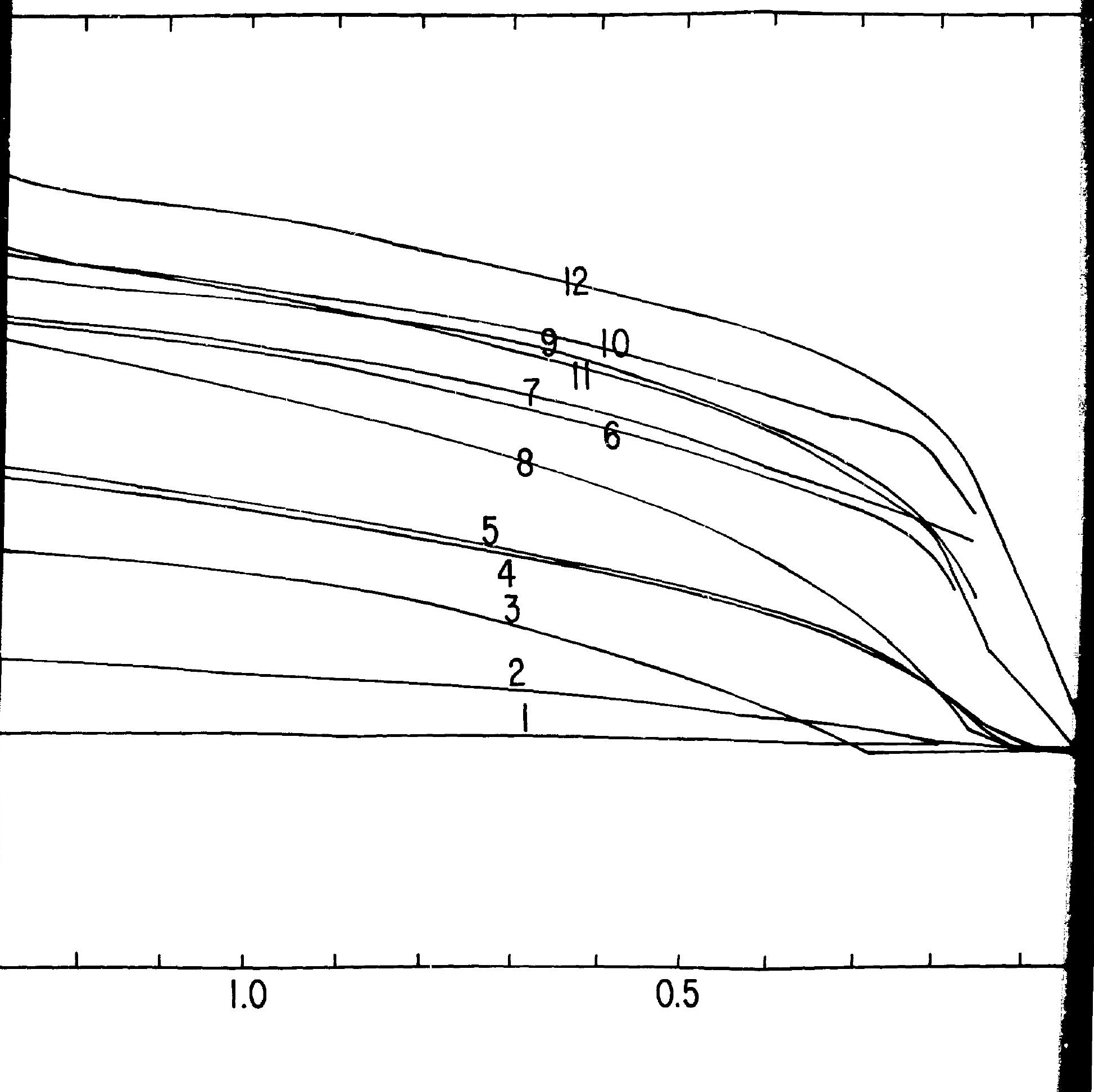




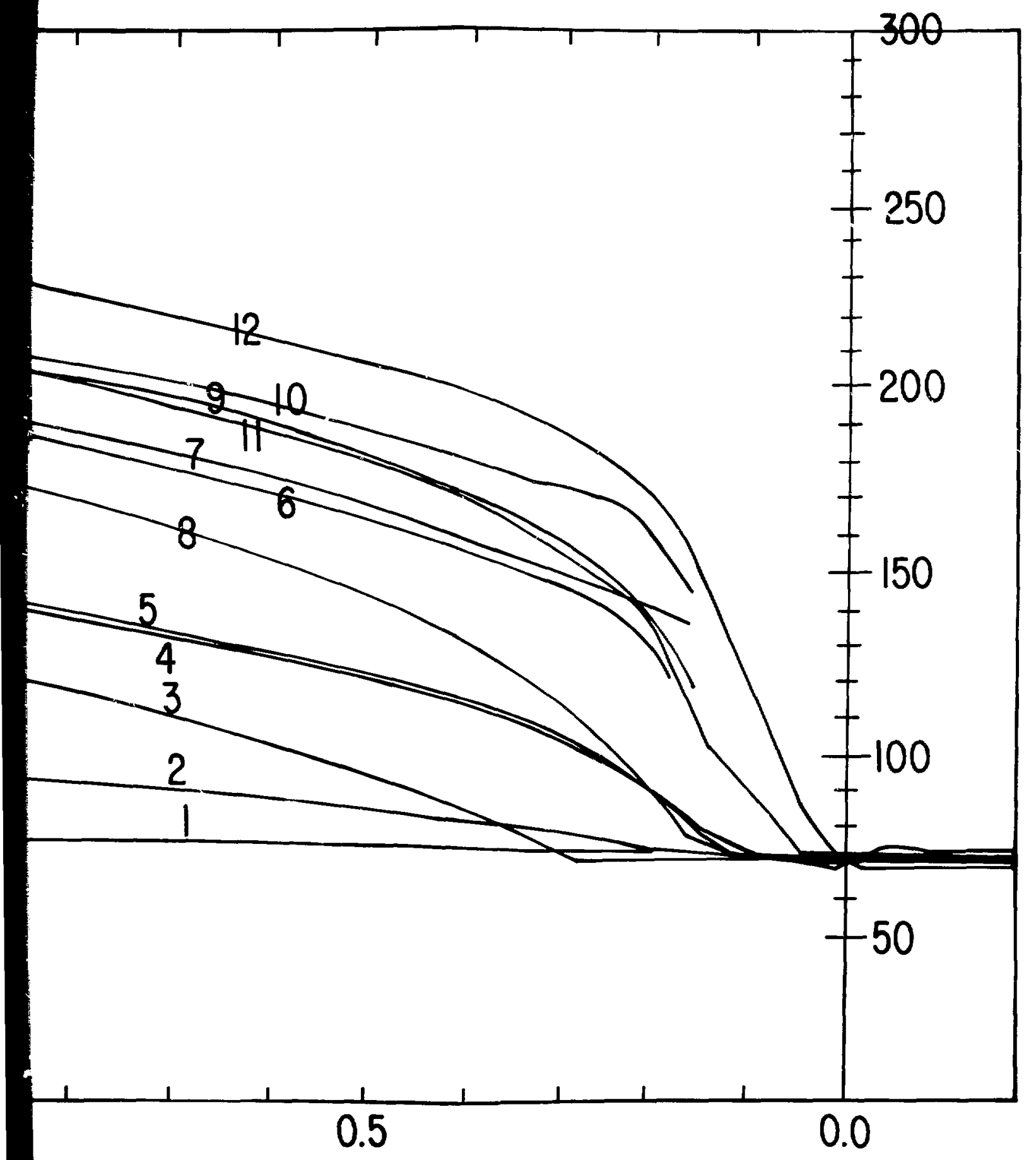

21 

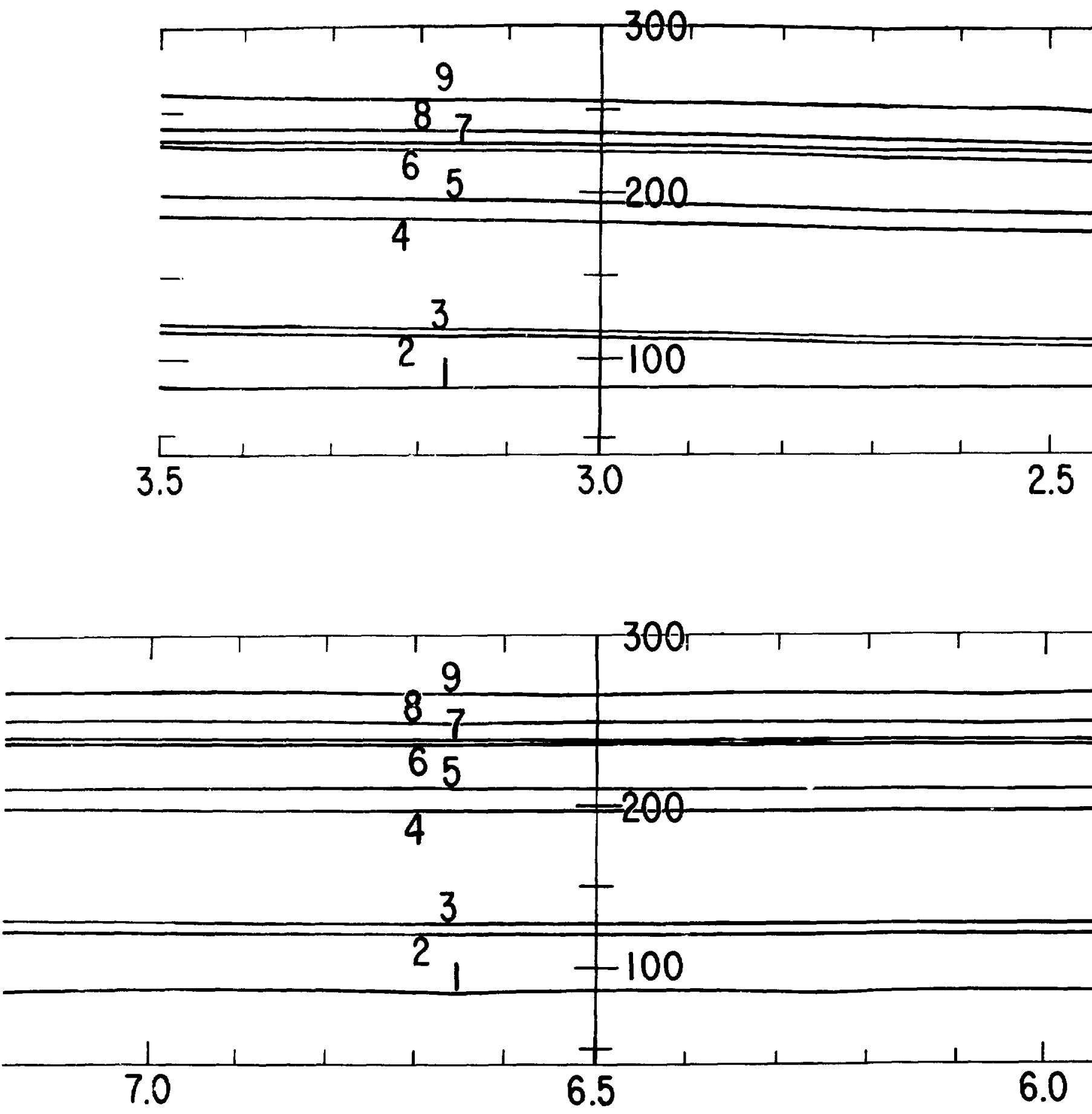


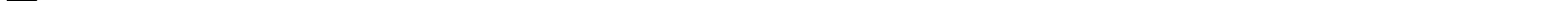



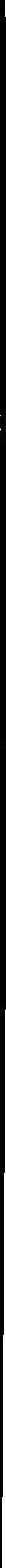

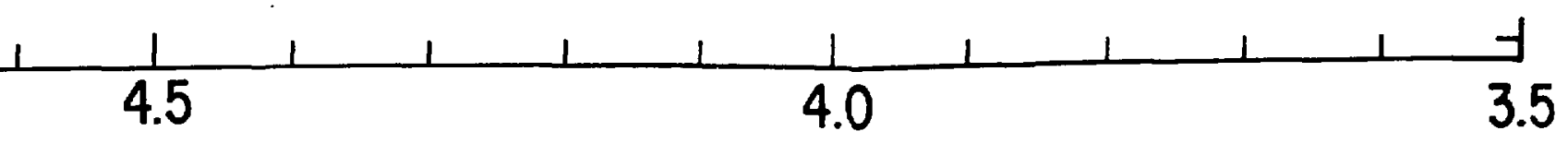


There are two basic areas of concern assoclated with the use of ofl in switches. They are the generation of explosive gas from submerged arcing in oll and the formation and gruwth of $f 11 \mathrm{~m}$ between contact surfaces submerged in o11. The gas generation problem would result if BP or PSCS were triggered open inadvertently while conducting current. The film growth prublem is inherent in the system even during normal operation.

Explosive gases, mainiy hydrogen and methane, are generated as bypruducts of decomposition when oll is exposed to an electric arc. Silfcone oft generates more gas than mineral transformer ull. One 1iterature source reports a gas evolution rate of $6 \mathrm{ml} / \mathrm{A}-\mathrm{s}$ for 100 centistoke silicone ofl. Using this figure, an arc at $25 \mathrm{kV}$ would generate gas at the rate of $150 \mathrm{\ell} / \mathrm{s}$. Because silicone ofl is not flammable in oxygen concentrations less than $80 \%$, the primary hazard would be a gas explosion. Dur recommendation is that the switch be equipped with elther a sultable rupture disc that would remuve the silicone oll during an unexpected pressure rlse or a high volume ventilation system to remove any explosive gases from the area. Inert gas cover should be used with any contalned or closed submerged oll switch.

Film gruwth on contact surfaces is a recognized problem in circuit breaker design and is primarily dependent on operating temperature. Lemelson ${ }^{B 2}$ suggests that the fallure time for copper to copper contacts decreases by an order of magnitude when the operating temperature is raised from $40^{\circ} \mathrm{C}$ to $100^{\circ} \mathrm{C}$. For this reason ANSI Standard C37.04 11mits; the hottest spot temperature for a silver alloy contact in a circuit breaker to $90^{\circ} \mathrm{C}$. The hottest cgntact temperature in PSCS during the first heat rise test was $141^{\circ} \mathrm{C}$. Lee ${ }^{\mathrm{B}}$ Indicates that the film may be partially removed by the surface shear action when the contacts are operated. 0il temperature should be periodically monitored in the LCTF switches as a precautionary measure and occastonal switch operation performed to remove the film.

\section{REFERENCES}

B1. Frank M. Clark, Insulat1ng Materlals for Design and Englneering Practice, John Wiley and Sons, Inc., New York and London, 1962.

B2. K. Leme1son, "About the Fallure of Closed Heavy Current Contact Pleces in Insulating Col1 at High Temperatures", IEEE Trans,, PHP, 9, No. 1 (March 1973).

B3. T. H. Lee, Physics and Engineering of High Power Switches, MIT Press, Cambridge and London, 1975. 


\author{
APPENDIX C \\ PROBLEMS ENCOUNTERED WITH PROTOTYPE LCTF EQUIPMENT
}

The following is a sumary of problems encountered with the equipaent tested for use in LCTE.

1. The air cylinder on both BP and PSCS is mounted in elongated holes. During the test, one of these cylinders muved in its holes, making repositioning necessary. A set screw is recomended.

2. Twice during the tests, the air cylinder of BP stuck in a midpoint position and to change its positon by remute contrul was not possible. Movement was done manually. The problem seerns to originate in the shuttle valve system.

3. Clearance needs to be allowed in frunt of DCCB. Plasma generated during an interruption caused a breakdown between conductors approximately 10 inches in front of the breaker. Clearance guidelines are usually supplied with this type of equipment.

4. The clearance on connections between BP and DCCB needs to be increased. Several busbars had to be wrapped with polyethelene to prevent breakdown.

5. If two DCCB's are used in serles, a voltage grading network should be used. There was no steady state voltage sharing between the two tested unt 11 a $100 \mathrm{k} \Omega$ resistor was connected in parallel across each interrupter.

6. The timing of DCCB changes with erusion. Approximately 5 ms difference in contact parting time was noted after 100 operations. 


\author{
APPENDIX D \\ TIMING MEASUREMENTS ON PROTOTYPE SWITCHES FOR LCTF
}

Table DI is a summary of the mean opening, closing, delay, and jitter times measured on new prototype LCTF equipment. The $1 \mathrm{imit}$ switches on BP and PSCS were used for their measurements, while the parting of the Intermediate contacts on DCCB was used for 1 ts measurement. The fitter here is defined as the standard deviation from the mean.

TABLE DI

OPENING, CLOSING, DELAY, AND JITTER TIMES FOR LCTF SWITCHES

SWITCH

OPENING (ms)

CLOSING (ms)

DELAY JITTER COMPLETION JITTER DELAY JITTER COMPLETION JITTER

$\mathrm{BP}(125 \mathrm{ps} 1)$

$\operatorname{PSCS}(125 \mathrm{ps1}) \quad 31.9 \quad 0.30$

77.9

$0.63 \quad 38.7$

1.8

229.4

3.9

$\operatorname{DCCB}(125 \mathrm{Vdc}) 25.3 \quad 0.29$

76.5

$0.64 \quad 41.0$

0.41

429.6

4.9

*

*

$-\cdots \quad 154.4$

4.9

\footnotetext{
*The high fitter discussed in the text is given here.

Th1s jitter was not apparent from this contact parting measurement.

The critical time is the time when the arc moves from the Intermediate contacts into the arc chute.

The jitter for that process is approximately $\pm 3 \mathrm{~ms}$.
} 
APPENDIX E

PHOTOGRAPHS OF SWITCHES IN TEST FACILITY.

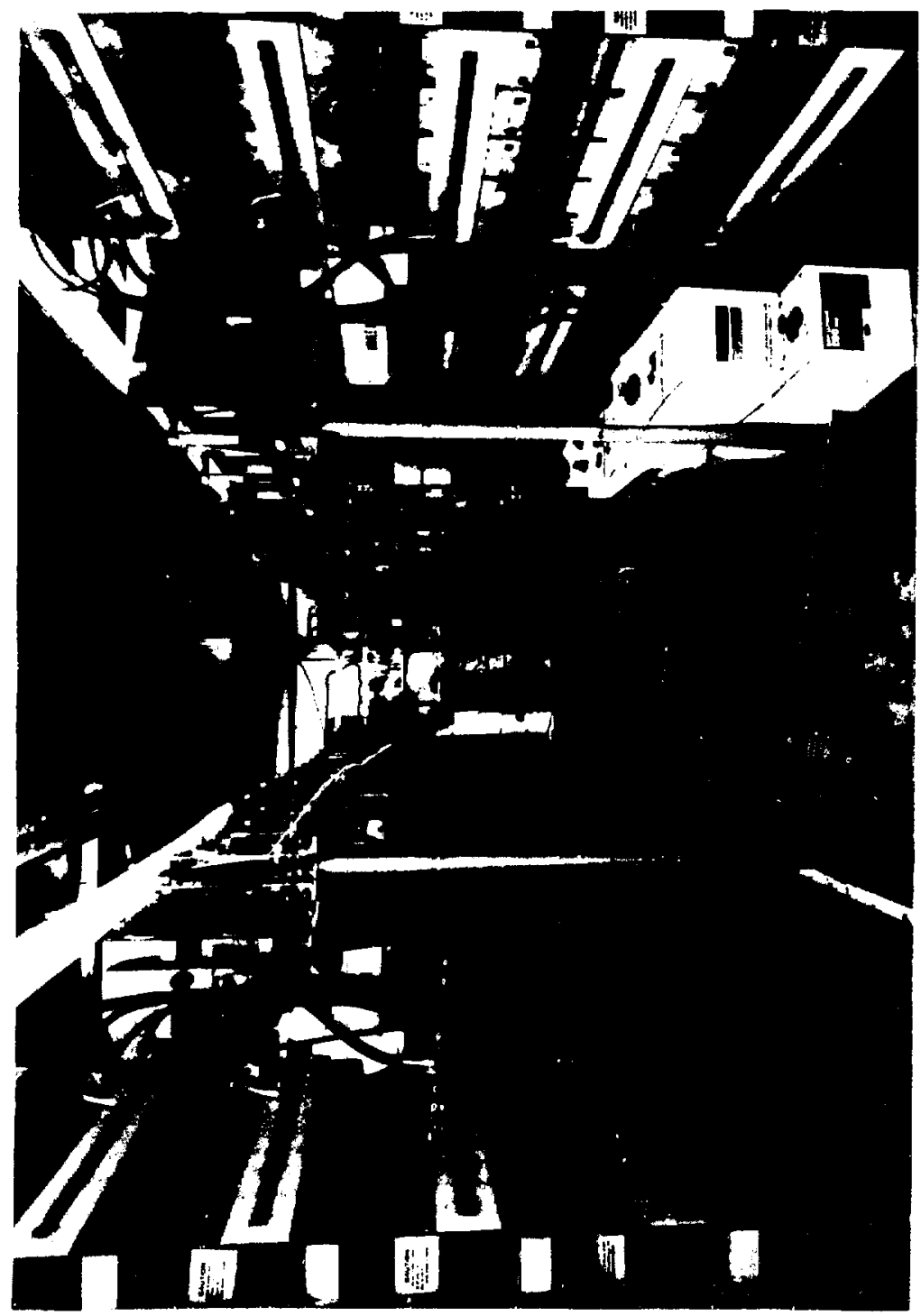

 


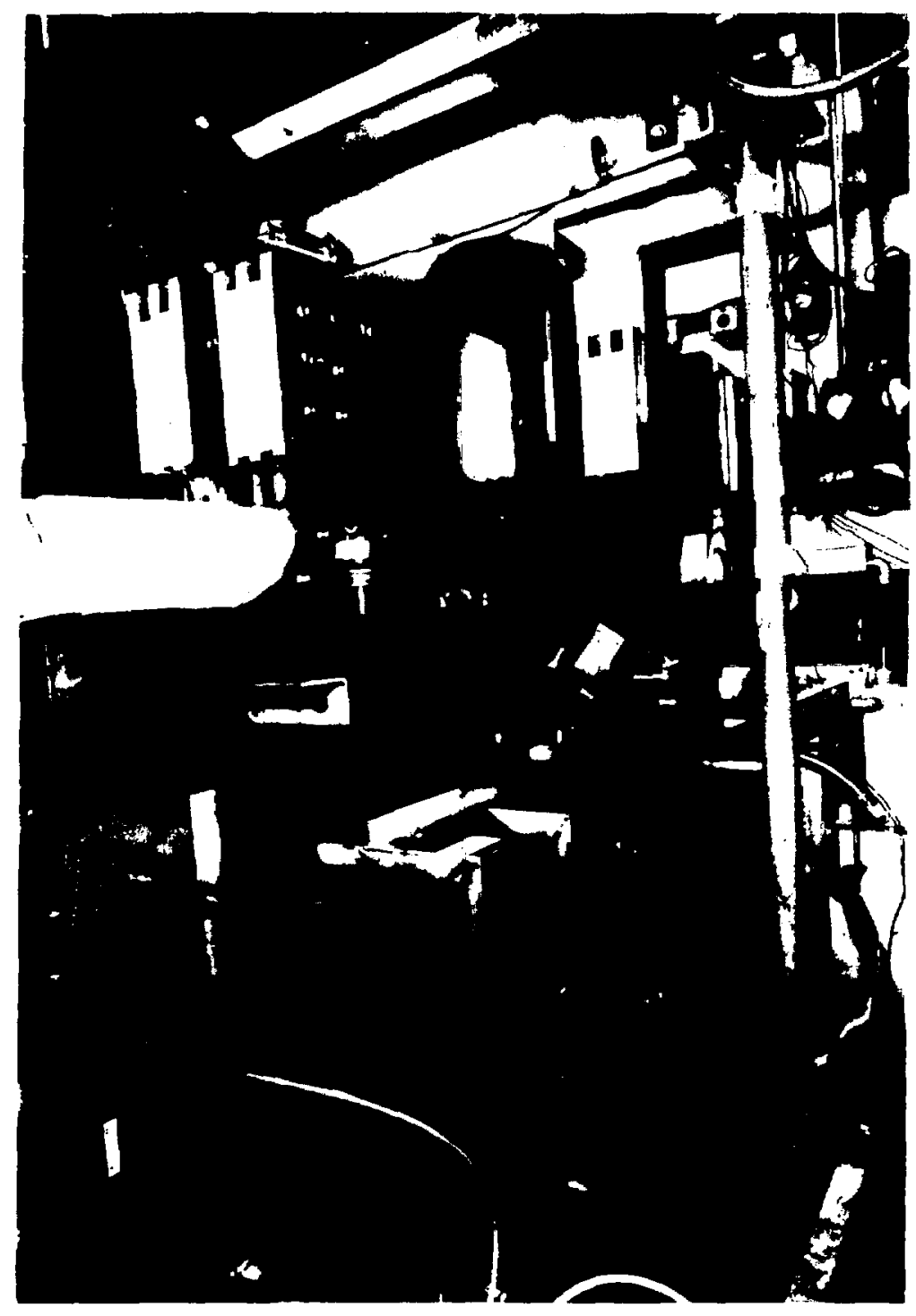

Fig. E2. BP in foreground and PSCS in background. 


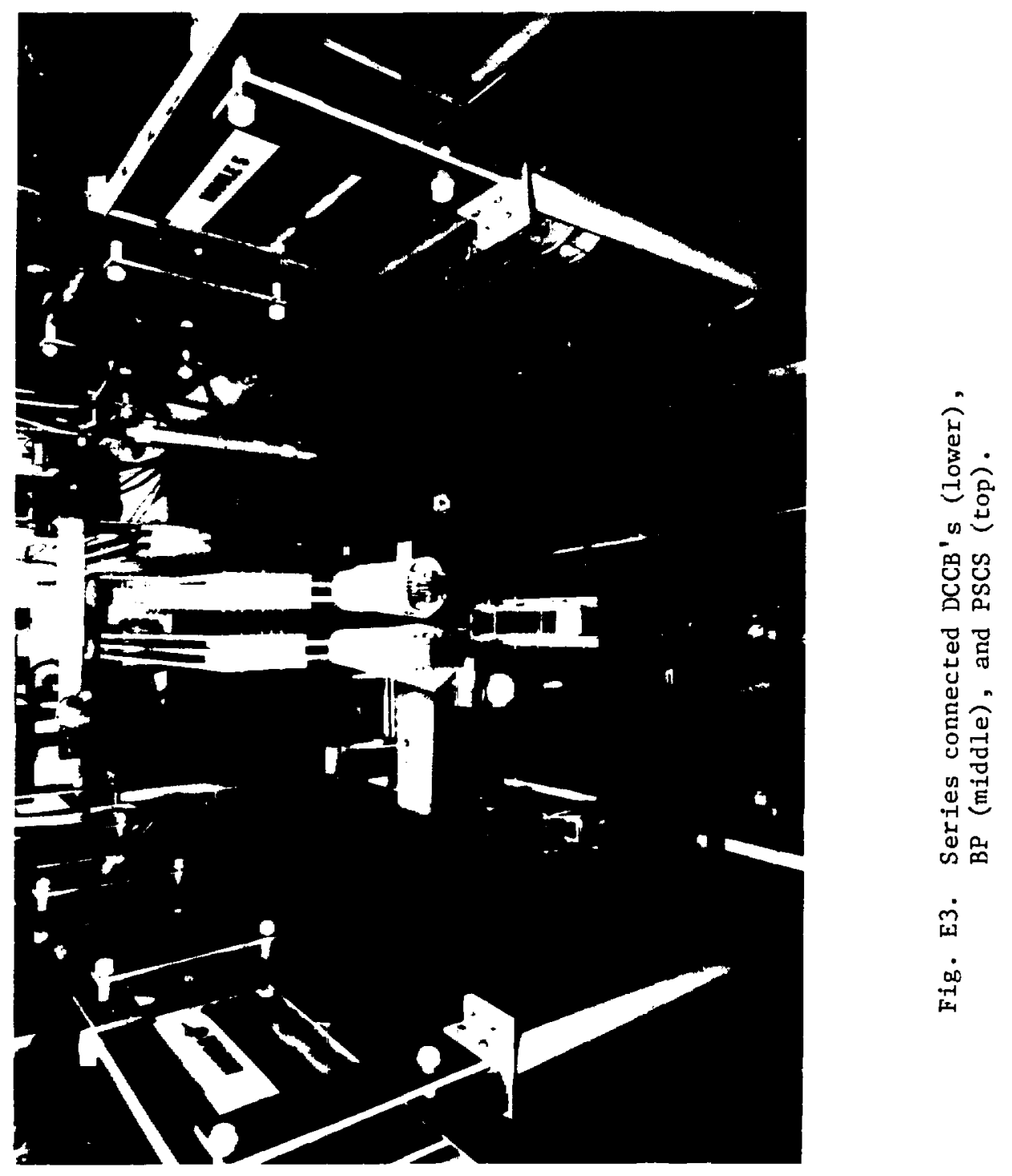




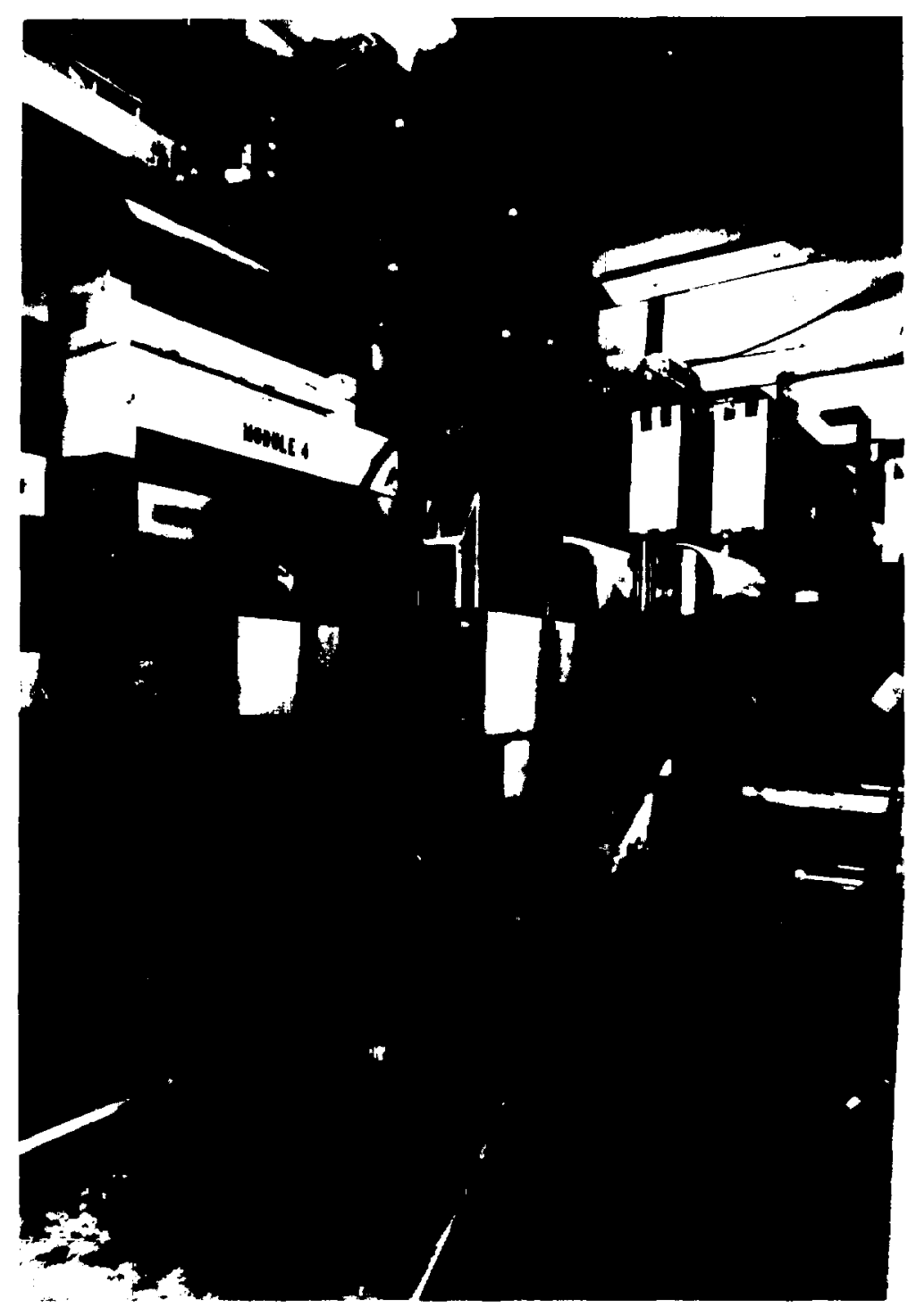

Fig. E4. Series connected DCCB's (Ieft) and BP (right). 


\section{APPENDIX F}

REPRESENTATIVE WAVEFORMS TAKEN DURING TESTS ON A SINGLE DC INTERRUPTER
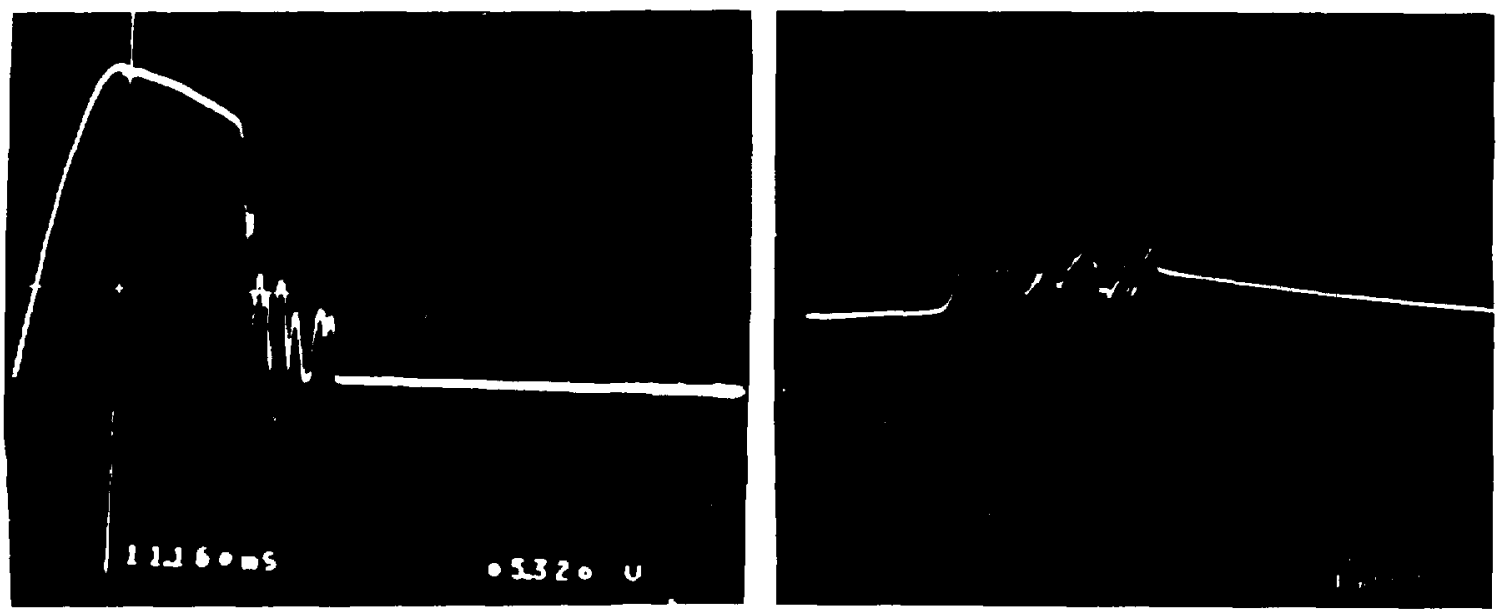

a. Breaker current. Peak current is $21 \mathrm{kA}$. b. Breaker voltage.

Peak voltage is $5.8 \mathrm{kV}$. Recovery voltage is $2.1 \mathrm{kV}$.

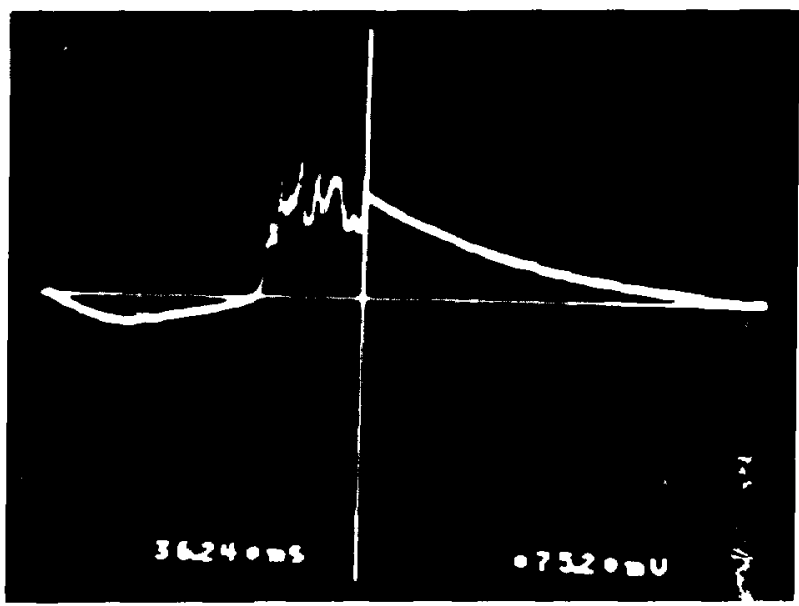

c. Reststor current. Transfer current is $13.5 \mathrm{kA}$.

Fig. Fl. Interruption at $2.1 \mathrm{kV}$ showing multiple restrikes. Time scales are different. 


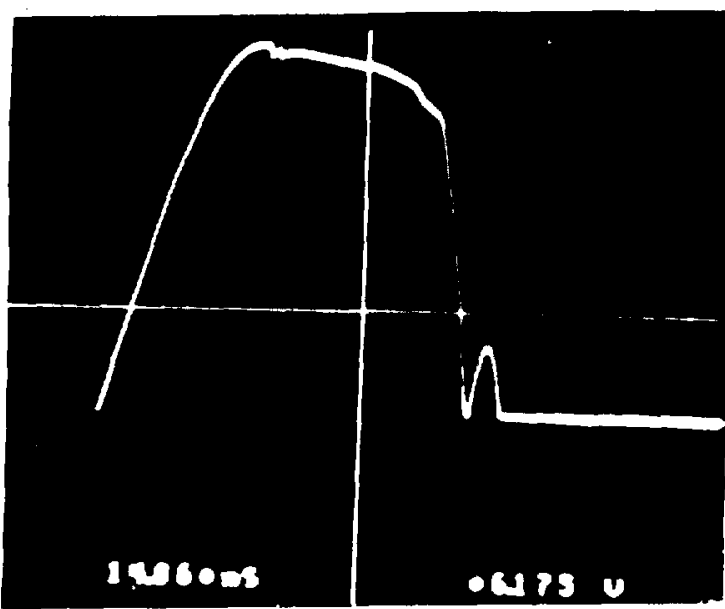

a. Breaker current. Peak current is $25 \mathrm{kA}$.

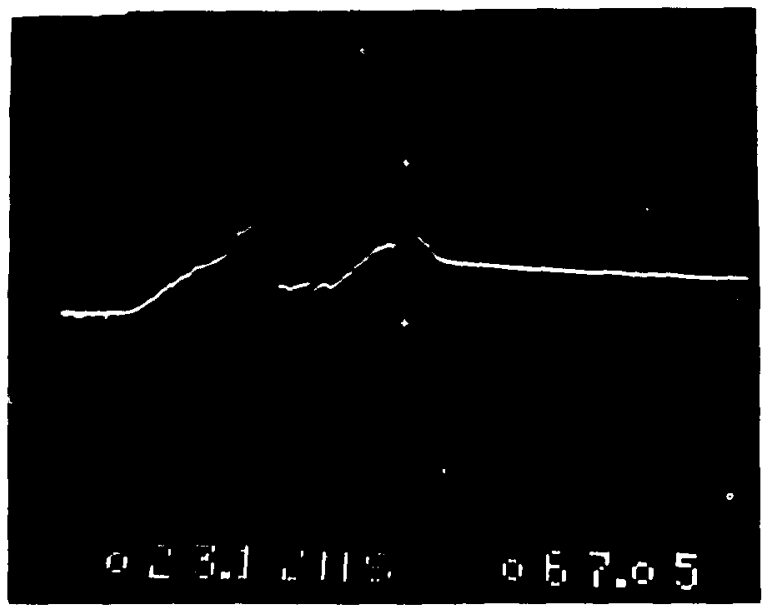

b. Breaker voltage. Peak voltage is $6.7 \mathrm{kV}$. Recovery voltage is $2.3 \mathrm{kV}$.

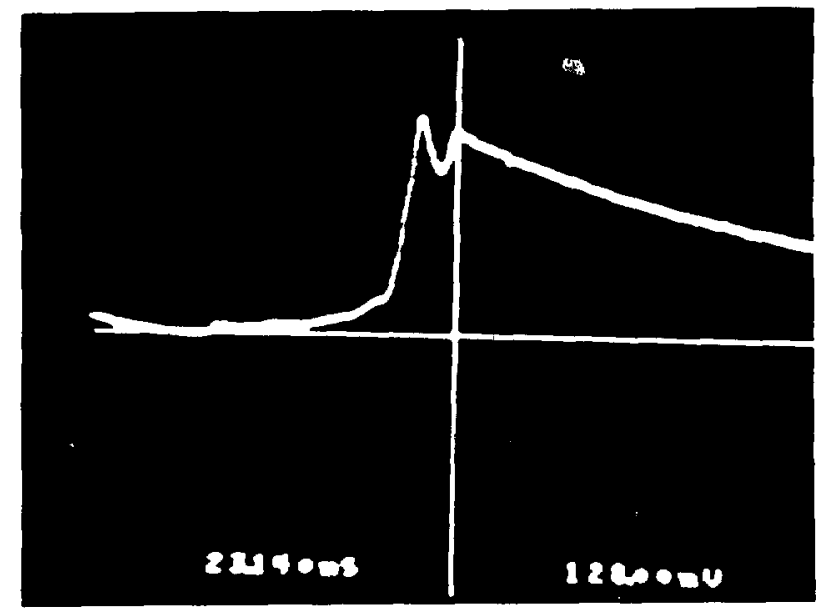

c. Resistor current. Transfer current is $23 \mathrm{kA}$.

F1g. F2. Interruption at $2.3 \mathrm{kV}$ showing single restrike. Time scales are different. 


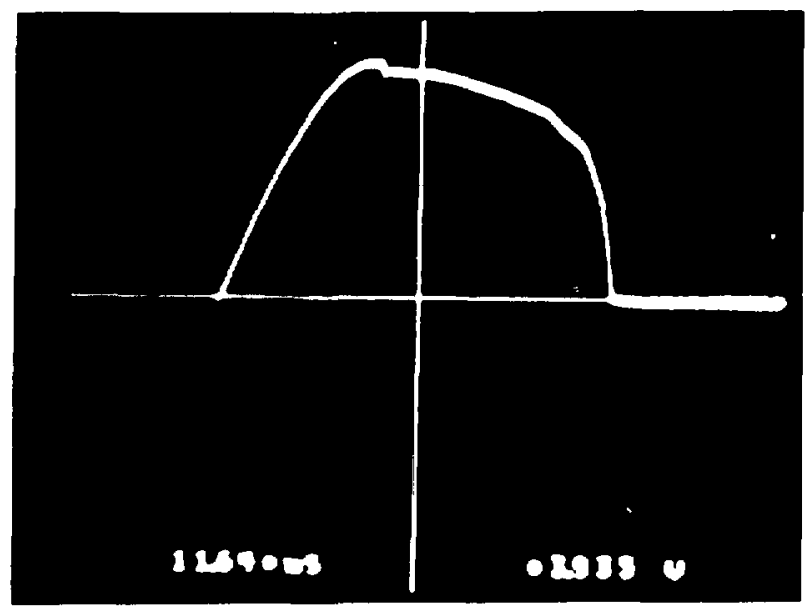

a. Breaker current.

Peak current is $16 \mathrm{kA}$.

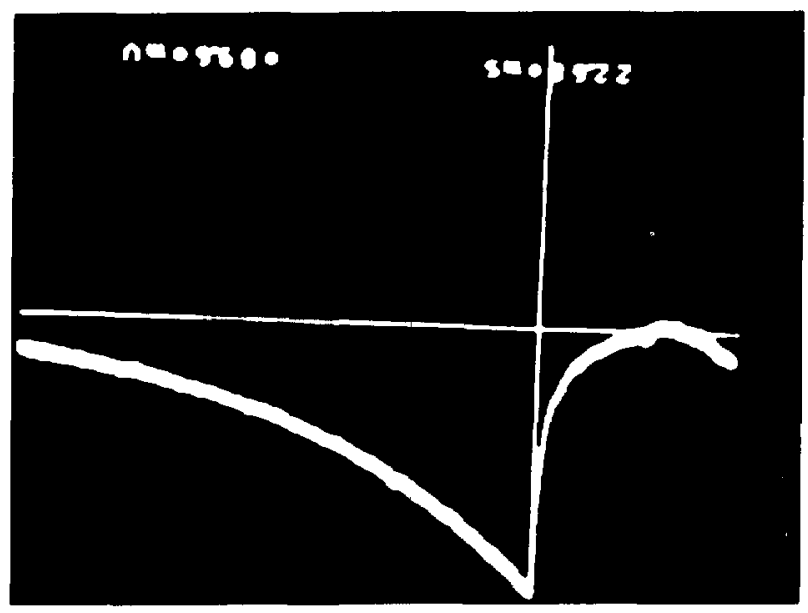

b. Resistor current.

Transfer current is $14 \mathrm{kA}$.

Fig. F3. Interruption at $1.1 \mathrm{kV}$ showing no restrikes.

Time scales are different. Voltage waveform not available. 


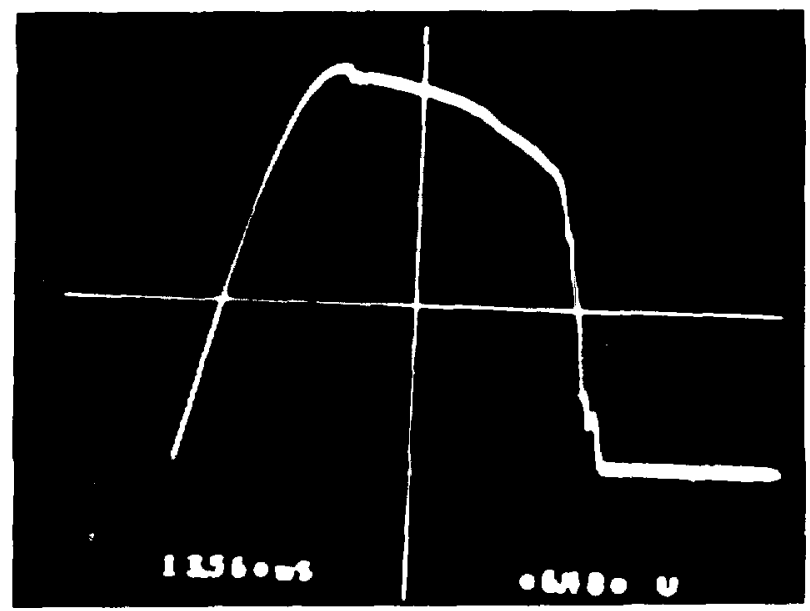

a. Breaker current.

Peak current is $26 \mathrm{kA}$.

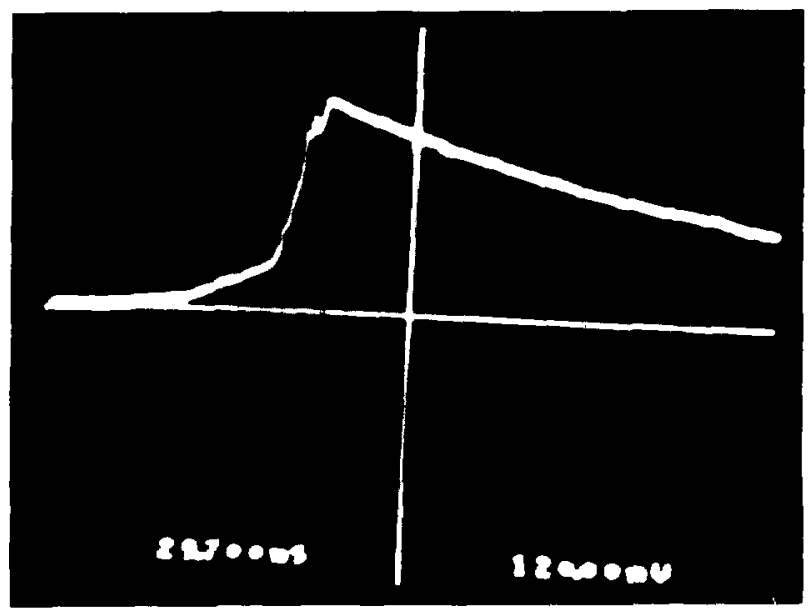

b. Resistor current.

Transfer current is $24 \mathrm{kA}$.

Fig. F4. Interruption at $1.6 \mathrm{kV}$ showing no restriking, but some hesitation at current zero. Time scales are different. Voltage waveform not avallable. 


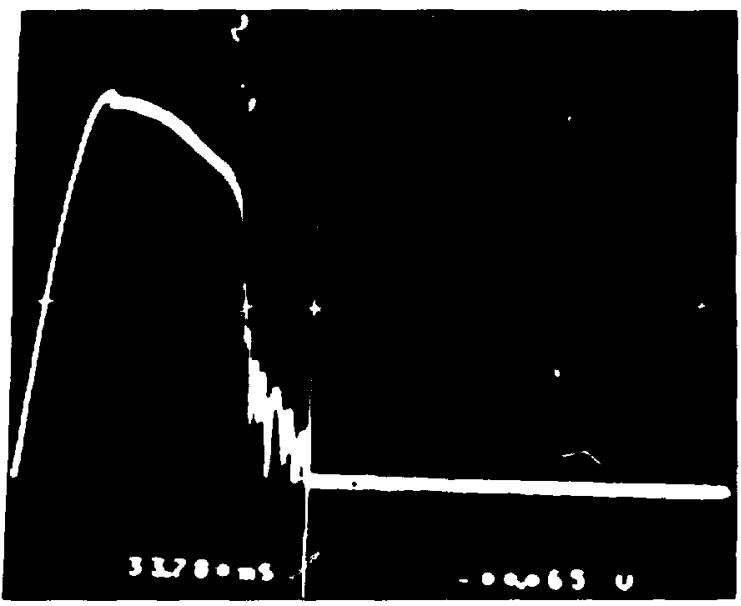

a. Breaker current.

Peak current is $25 \mathrm{kA}$.

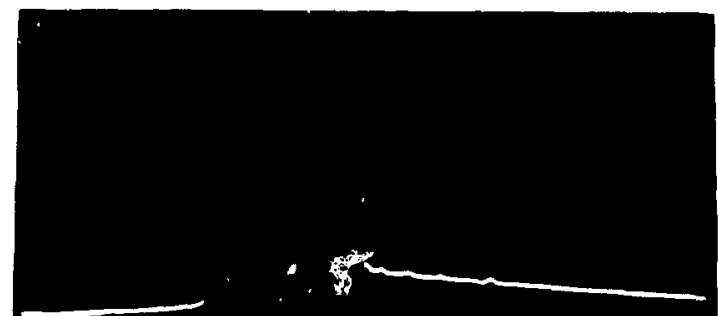

b. Breaker voltage.

Peak voltage is $5 \mathrm{kV}$.

Recovery voltage is $2 \mathrm{kV}$.

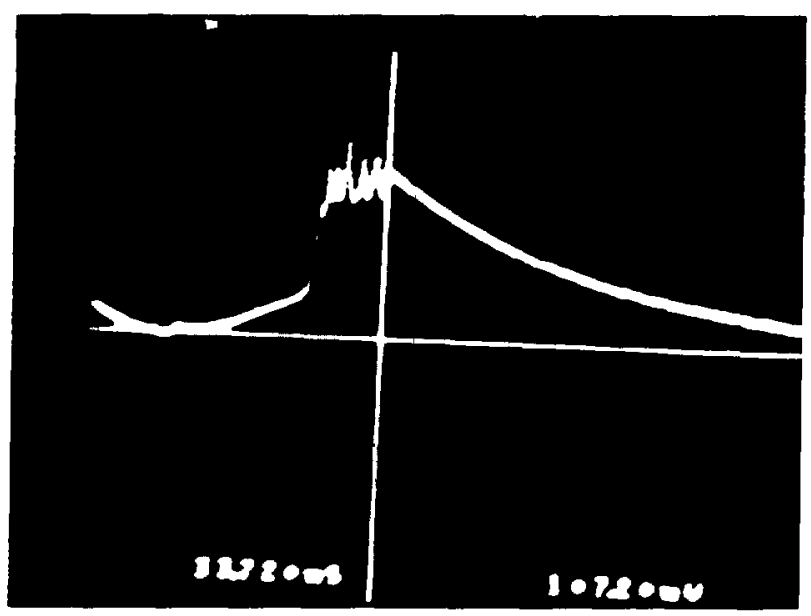

c. Resistor current. Transfer current is $23 \mathrm{kA}$.

Fig. F5. Interruption at $2.0 \mathrm{kV}$ showing multiple restrikes. Time scales are different. 